\title{
Essence of the Compensation Plan in the Process of Motivation in Multi-Level Marketing (MLM). A Case Study
}

\author{
Michał Roman ${ }^{1}\left(\mathbb{D}\right.$, Marta Wasiak $^{2}$, Monika Roman ${ }^{1, *}{ }^{\circledR}$, Kamil Roman $^{3} \oplus$, Arkadiusz Niedziółka ${ }^{4}$, \\ Andrzej Krasnodębski ${ }^{4}$ and Sylwia Królak ${ }^{2}$ \\ 1 Institute of Economics and Finance, Warsaw University of Life Sciences, 02-787 Warsaw, Poland; \\ michal_roman@sggw.edu.pl \\ 2 Public Relations Student Research Group, The Economic Department, Warsaw University of Life Sciences, \\ 02-787 Warsaw, Poland; marta.k.wasiak@gmail.com (M.W.); sylwiakrolak@onet.pl (S.K.) \\ 3 Institute of Wood Sciences and Furniture, Warsaw University of Life Sciences, 02-787 Warsaw, Poland; \\ kamil_roman@sggw.edu.pl \\ 4 Faculty of Agriculture and Economics, University of Agriculture in Krakow, 31-120 Krakow, Poland; \\ arkadiusz.niedziolka@urk.edu.pl (A.N.); andrzej.krasnodebski@urk.edu.pl (A.K.) \\ * Correspondence: monika_roman@sggw.edu.pl
}

check for updates

Citation: Roman, M.; Wasiak, M.; Roman, M.; Roman, K.; Niedziółka, A.; Krasnodębski, A.; Królak, S. Essence of the Compensation Plan in the Process of Motivation in Multi-Level Marketing (MLM). A Case Study. Sustainability 2021, 13, 8738. https://doi.org/10.3390/ su13168738

Academic Editors: Paola Scorrano, Monica Fait, Michael Christofi, Enrico Battisti and Francisco José Liébana-Cabanillas

Received: 12 June 2021

Accepted: 30 July 2021

Published: 5 August 2021

Publisher's Note: MDPI stays neutral with regard to jurisdictional claims in published maps and institutional affiliations.

Copyright: (c) 2021 by the authors. Licensee MDPI, Basel, Switzerland. This article is an open access article distributed under the terms and conditions of the Creative Commons Attribution (CC BY) license (https:/ / creativecommons.org/licenses/by/ $4.0 /)$.

\begin{abstract}
The objective of the article is to present the compensation plan and the possibilities resulting from cooperation with FM World. The study provides the characteristics of the market economy compensation system, especially the functions, goals and traditional compensation forms as well as the essence of the key motivation theories for organization management and the characteristics of the most important ones. The term Multi-Level Marketing (network marketing) is discussed, especially the nature of that sector, controversies and possibilities. The company, FM World, is covered, especially the information on the products distributed and services. The compensation plan and the incentive programme offer applied in the company are provided in detail. The study involved the use of a diagnostic survey. The group of respondents included 107 FM World distributors and cooperants with the Rentierzy.FM structure. The level of satisfaction of the respondents with the cooperation and the compensation plan offered are investigated; satisfaction with the incentive programmes available and the perspectives of further cooperation with the company were determined.
\end{abstract}

Keywords: motivation; compensation; Multi-Level Marketing; system; Poland

\section{Introduction}

The article offers a closer look at Multi-Level Marketing. In Poland, it is still little known, even though its origins can be traced back to the United States, to the early 20th century. Currently, it is thriving all across the world, winning new markets and expanding at a growing scale [1].

The applicable literature does not seem to provide an unambiguous definition of network marketing, otherwise known as MLM (Multi-Level Marketing). As defined by the Federal Trade Commission (FTC), Multi-Level Marketing (MLM), otherwise known as network marketing, is "any marketing program in which participants pay money to the program promoter in return for which the participants obtain the right to (1) recruit additional participants, or to have additional participants placed by the promoter or any other person into the program participant's down line, tree, cooperative, income center, or other similar program grouping; (2) sell goods or services; and (3) receive payment or other compensation; provided that: (a) the payments received by each program participant are derived primarily from retail sales of goods or services, and not from recruiting additional participants nor having additional participants placed into the program participant's down line, tree, cooperative, income center, or other similar program grouping, and (b) the marketing program has instituted and enforces rules to ensure that it is not a plan in which 
participants earn profits primarily by the recruiting of additional participants rather than retail sales" [2].

FM World operates under network marketing, which means that a person who will join the group of distributors is given the possibility of building the so-called consumer network by welcoming other members to cooperate. The compensation of the so-called business partner depends on the effectiveness of the partner's work, namely the turnover generated by the partner's user group. Next to building the network, the distributor can provide direct selling of products and services found in the company portfolio. In that way, one can earn on the profit margin which, on average, accounts for $30 \%$ of the product price.

The authors of the article decided to have a closer look at network marketing as in Poland it is not quite popular. There is also a lack of detailed data on people working in this structure. The business model diverges from the traditional regular job considerably as it is based on the commission compensation plan and, over a few years, it allows for financial freedom, namely the so-called passive income generating constant revenues [1].

There are many network marketing controversies. State institutions responsible for market control all over the world undertake to verify thoroughly whether the operation of the enterprises operating in the MLM system complies with the law. It comes from the fact of striking similarity to the systems considered pyramid schemes. The similarity is, however, superficial only, and the ignorance of society can come from two reasons. First of all, reliable scientific elaborations are hardly available on the market. The major resources of knowledge on Multi-Level Marketing are manuals and textbooks developed by its practitioners, motivation speakers or coaches without true economic knowledge as well as blogs and forums, where the evaluation of the author's reliability is very difficult to verify. Second of all, if one undertakes to provide the characteristics of that phenomenon, they often do it superficially and very generally [1].

Despite many controversies and limited access to the literature on network marketing, it is a compensation-generating form that is worthwhile. In this paper, there are aspects closely connected to the idea of Multi-Level Marketing to help one understand it. On the example of a company operating in the MLM system, a compensation plan and the possibilities resulting from cooperation in such a system are presented.

\section{Literature Review}

\subsection{Essence of the Compensation Plan}

Compensation, according to Leksykon Zarządzania, means a payment for an employee's subordinated work under an employment relationship. The total compensation covers all the employee's benefits from the employer for employment, directly or indirectly, in cash or in kind [3]. The compensation plan is a process of developing and introducing the strategies and principles leading to the enterprise's accomplishment of goals. Compensation covers not only financial compensation but also intangible incentives [4].

The objective of the compensation plan is to develop such a pay structure that will be favourable in terms of the costs borne by the enterprise and, at the same time, attractive for competent employees; it will attract and motivate them to an increased engagement and a considerable effort [5]. The pay levels provided in the compensation plan should be decent for all the employees [6]. It means that they are to be satisfactory and adequate for the job, skills, knowledge and the abilities required [7]. In Poland, the amount of pay is regulated by the Ustawa o godziwych normach pracy (Decent Labour Norms Act) of 1938 which, over years, has been many times amended. It determines the minimum wage, and it requires that overtime, as working time exceeding $40 \mathrm{~h}$ a week, is to be additionally paid for, while the Ustawa o równej płacy (Equal Pay Act) of 1963 ensures equal pay irrespective of the employee's gender [8]. Borkowska identified four traditional forms of compensation [9]: time-based, piecework, task wage paid by day and on-commission. Despite numerous modifications, these forms are still widely applied [10]. An exception is piecework which, over the recent years, has been in decline [11]. 


\subsection{Importance of the Motivation Theory}

In the literature of the current business environment, we can find many definitions of motivation. The literature on the contemporary business environment is considered for review. Gredler, Broussard and Garrison defined motivation in a broad sense as an attribute that stimulates us to do something or not [12].

Different views emerge about internal and external motivation. According to Ryan and Deci, intrinsic motivation is understood as actions aimed at achieving satisfaction, not as separate consequences [13]. A person who is internally motivated takes up challenges and implements plans without external pressure. In turn, external motivation is defined as an activity carried out solely to receive a reward. The difference between external motivation and internal motivation is that due to internal motivation, activities are undertaken out of a passion to achieve happiness [14].

In the context of an employee's performance, motivation can be considered as a factor that induces an employee to achieve professional goals and, at the same time, justify the manner of their behaviour [15].

Motivation is an intermediary process or an inner state of the body that triggers or drives to act [16]. The one experienced by the employees from the employers is extrinsic motivation. According to the definition, it is a motivation that originates from factors beyond the individual. Behaviour motivated by reward and punishment managed by external forces is extrinsically determined [16]. One can differentiate between three levels of incentive: subordination, goal identification and engagement.

Subordination means performing tasks commissioned by the superior without investing one's own skills and energy. If the employer expressly communicates the benefits resulting from the result accomplished by the subordinate, the employee will accomplish the goal identification level where a desire to accomplish the idea appears in them, which enhances motivation. At the engagement phase, the employee assumes the company's goal to be their own, and their motivation increases as they realize that they are the only person entrusted with a given task and that they are the one the final effect depends on [17]. The employee does not always take a job only for the payment to make a living. Motivation theories are an attempt at accounting for such behaviours [18]. Satisfying a specific need does not always lead to ending the process. The next step is the emergence of a new desire, and the cycle must be repeated [19].

The primary goal of the motivation theory is the development of the employee activation actions model after the application of which the organization's effectiveness increases. There are many theories of motivation that most often relate to or affect employee satisfaction with work. There are three main categories of theory, namely content theories, process theories and reinforcement theories [20,21]. Table 1 presents a systematic approach to selected motivation theories.

Table 1. Division of selected motivation theories.

\begin{tabular}{|c|c|c|}
\hline Group & Theory & Author \\
\hline \multirow{4}{*}{$\begin{array}{l}\text { Content } \\
\text { theories }\end{array}$} & Hierarchy of needs & Abraham Maslow \\
\hline & ERG theory of needs & Clayton Alderfer \\
\hline & Two-factor motivation theory & Frederick Herzberg \\
\hline & Theory of a trichotomy of needs & David McClelland \\
\hline \multirow{4}{*}{$\begin{array}{l}\text { Process } \\
\text { theories }\end{array}$} & Expectancy theory & $\begin{array}{c}\text { Victor Vroom, Edward E. Lawler, } \\
\text { Lyman W. Porter }\end{array}$ \\
\hline & Theory of justice & John Stacey Adams \\
\hline & Goal-setting theory & Edwin Locke, Garry Latham \\
\hline & Cognitive evaluation theory & Edward L. Deci, Richard M. Ryan \\
\hline \multirow{2}{*}{$\begin{array}{l}\text { Theories of } \\
\text { reinforcement }\end{array}$} & Reinforcement theory & Burrhus Frederic Skinner \\
\hline & Social learning theory & Albert Bandura \\
\hline
\end{tabular}


Content theories explain what human needs must be satisfied to ensure a satisfactory lifestyle and the role of work in satisfying desires. While trying to answer the question of what factors motivate a person to work, process theories focus on explaining the reasons for which employees select specific behaviour variants on the way to satisfy their needs. Reinforcement theories, however, assume that people behave the way they have learnt in the past and they associate some behaviours with pleasure and some with negative effects [22].

\subsubsection{Content Theories of Motivation}

The first theory discussed is the classic theory by Maslow. According to him, a person is motivated by the hierarchic system of five needs: physiological, safety, social, esteem and self-actualization [23]. According to A. Maslow, each of the needs can be felt only once the previous one is satisfied [24]. In terms of motivation at work, each of them corresponds to another employee motivation method. Next to the basic physiological needs, the author included additional needs, namely the ones that can be revealed only in some individuals. These are the needs of knowledge, understanding and curiosity as well as the sense of beauty, order and harmony. The author found them to be closely related to the needs of self-actualization [18]. Smith and Cronje explained that the theory described above is based on the statement that people want to achieve more and more in life, and their needs are prioritized according to their relevance. Content theories of job satisfaction resulting from Maslow's hierarchy of needs revolve around the needs and satisfaction of employees. Maslow's hierarchy of needs is the basis for theories dealing with job satisfaction [25].

Employees satisfy their needs starting from those at the bottom of the pyramid all the way to those at the top. A lower-level need must be at least partially satisfied for the individual to feel a higher-level need. Table 2 presents a comparison of the needs in human life to the person's needs at work.

Table 2. Characteristics of human needs in life and in the organization.

\begin{tabular}{|c|c|c|}
\hline \multirow{2}{*}{$\begin{array}{l}\text { Group of } \\
\text { Needs }\end{array}$} & \multicolumn{2}{|c|}{ Examples of Needs } \\
\hline & In Everyday Life & In the Organization \\
\hline $\begin{array}{c}\text { Physiological } \\
\text { needs }\end{array}$ & $\begin{array}{l}\text { - } \quad \text { the air } \\
\text { - } \quad \text { food } \\
\text { - } \quad \text { thirst }\end{array}$ & $\begin{array}{ll}- & \text { pay } \\
- & \text { good lighting and temperature } \\
- & \text { staff rooms }\end{array}$ \\
\hline Needs of safety & $\begin{array}{l}\text { - } \quad \text { roof over one's head } \\
\text { - } \quad \text { clothes } \\
\text { - } \quad \text { a lack of material concerns }\end{array}$ & $\begin{array}{l}\text { - } \quad \text { continuity of employment } \\
\text { - } \quad \text { medical care } \\
\text { retirement scheme }\end{array}$ \\
\hline $\begin{array}{c}\text { Needs of } \\
\text { belongingness }\end{array}$ & $\begin{array}{l}-\quad \text { having a family } \\
\text { - } \quad \text { friendship } \\
\text { - } \quad \text { acceptance }\end{array}$ & $\begin{array}{l}\text { - } \quad \text { atmosphere in the organization } \\
\text { - } \quad \text { social interactions, integration } \\
\text { - } \quad \text { leadership }\end{array}$ \\
\hline $\begin{array}{l}\text { Needs of } \\
\text { respect }\end{array}$ & $\begin{array}{l}\text { - } \\
\text { - } \\
\text { recocial status }\end{array}$ & $\begin{array}{ll}\text { - } & \text { position } \\
\text { - } & \text { company car } \\
\text { - } & \text { title }\end{array}$ \\
\hline $\begin{array}{l}\text { Needs of self- } \\
\text { actualization }\end{array}$ & $\begin{array}{l}\text { - } \\
\text { - } \\
\text { - } \\
\text { desponsibinctiveness }\end{array}$ & $\begin{array}{l}\text { - tasks adequate to the education } \\
\text { background } \\
\text { - } \quad \text { participation in training } \\
\text { decision making }\end{array}$ \\
\hline
\end{tabular}

Source: [26].

Interpreting the needs hierarchy by A. Maslow in the context of work engagement, one must note that the company should, first of all, provide the security of the basic needs of an individual: financial needs or employment security and stability. Otherwise, the individual will not be able to enjoy and appreciate the available development opportunities. 
Similarly, as in Maslow's theory of needs, also in the ERG theory, one can refer to motivation in the organization [27]. C. Alderfer claimed that human action can be a result of the interaction of many needs at the same time. That assumption helps a better understanding of the reasons for the individual's behaviour at a given moment. However, introducing an element of regression and frustration means that in a situation in which an individual faces a problem with satisfying higher-level needs, there is a regression to satisfying the lower-level needs and the temporal human accomplishments are denied $[28,29]$.

Herzberg's theory of two factors (motivator-hygiene) derives from research on job satisfaction and its causes [21]. During his observation, Herzberg noted five job traits that bring satisfaction: achievement, recognition, work itself, responsibility and promotion. At the other end of the spectrum, Herzberg characterized management approaches, supervision, wages, relationships at work and working conditions as factors that can negatively affect workers [30,31].

The division of factors affecting satisfaction at work shows that the reward systems proposed by the organization should ensure both financial compensation and non-financial incentives. Herzberg concluded that even complete elimination of the effect of negative hygiene factors does not ensure the employee's motivation. The factors' development process can only minimise the level of dissatisfaction with work. Motivation can be acquired only by activating motivators [32,33].

Another, extremely important motivation theory is the needs trichotomy theory developed by McClelland, who divided the basic human needs into three groups [34]: the need of power, the need of affiliation and the need of achievement. McClelland's theory of the need for success states that some people drive to success by seeking "personal achievements, not rewards themselves" [21]. The theory focuses especially on the needs of managers. The conclusion coming from the McClelland theory is a conviction that the needs can be experience-like: learnt or unlearnt. It means that managers can manage the work process, affect the behaviour of the employees and adjust their needs to the working environment and to the goals of the enterprise. It is important that each employee feels each of the three types of needs; however, usually one of the needs dominates considerably. Such an employee must be assigned an adequate job in the company which, at the same time, facilitates the accomplishment of the company's goals and the employee's personal goals [35].

All of the four motivation theories discussed, as content theories, search for the answer to the question: What drives human behaviour? Table 3 presents a breakdown of needs provided in respective theories.

Table 3. Comparison of the content theories.

\begin{tabular}{ccccc}
\hline Theory Need & $\begin{array}{c}\text { Hierarchy of } \\
\text { Needs by } \\
\text { Maslow }\end{array}$ & $\begin{array}{c}\text { ERG Theory } \\
\text { of Needs by } \\
\text { Alderfer }\end{array}$ & $\begin{array}{c}\text { Two-Factor } \\
\text { Theory by } \\
\text { Herzberg }\end{array}$ & $\begin{array}{c}\text { Trichotomy } \\
\text { of Needs by } \\
\text { McClelland }\end{array}$ \\
\hline $\begin{array}{c}\text { Transcendence } \\
\text { Self-actualization }\end{array}$ & $\mathrm{X}$ & $\mathrm{X}$ & $\mathrm{X}$ & $\mathrm{X}$ \\
Aesthetics & $\mathrm{X}$ & $\mathrm{X}$ & $\mathrm{X}$ & $\mathrm{X}$ \\
Knowledge & $\mathrm{X}$ & $\mathrm{X}$ & $\mathrm{X}$ & $\mathrm{X}$ \\
Values & $\mathrm{X}$ & $\mathrm{X}$ & $\mathrm{X}$ & $\mathrm{X}$ \\
Affiliation & $\mathrm{X}$ & $\mathrm{X}$ & $\mathrm{X}$ & $\mathrm{X}$ \\
Love & $\mathrm{X}$ & $\mathrm{X}$ & $\mathrm{X}$ & $\mathrm{X}$ \\
Security & $\mathrm{X}$ & $\mathrm{X}$ & $\mathrm{X}$ & \\
Physiological & $\mathrm{X}$ & $\mathrm{X}$ & $\mathrm{X}$ & \\
\hline
\end{tabular}

Source: $[18,23,27,32]$.

A comparison of the content theories of motivation shows that each of them, in fact, refers to the same needs. The springboard for the content theories of motivation is a conviction that an unsatisfied need triggers tension and a lack of equilibrium. To recover it, 
a goal is specified to satisfy the need and a path of behaviour is chosen to ensure the goal accomplishment and need satisfaction.

\subsubsection{Motivation Process Theories}

The first of the motivation process theories has been discussed by American psychologist Vroom and further developed by Porter and Lawler. It has been referred to as the expectancy theory [36]. Vroom's expectation theory assumes that behaviour is the result of choices that can be prioritized. The main rule is to get satisfaction and minimize employee dissatisfaction. Personalized factors such as personality and skills, in turn, affect performance [37].

According to it, motivation to work at a specific level of performance is a function of the desired result of action and the expectancy that the results will be accomplished [36]. V. Vroom opposed the traditional motivation model, assuming a new mechanism based on performance, namely efficiency [38]. He claimed that human desires are unlimited. A person has few needs; however, they drive them to action to satisfy the desires. People are rational as they expect that in the process of acting supported by an effort, their desires will be satisfied. They undertake specific actions when they expect that the result of the actions will have a specific value for them [39]. According to that theory, performance is affected by three factors: level of satisfaction with the effects of work, the impact of performance on other actions and knowledge of the values of the effects of work [40,41]. It shows that the individuals are satisfied with their work to such an extent to which their work provides them with what they desire and they are effective in work to such an extent to which performance leads to the accomplishment of what they desire [42].

Another theory worth mentioning is the justice theory developed by Adams. According to the author, a person will be motivated if treated fairly. People pursue social justice understood as receiving rewards connected with accomplishments at work. Fairness is thus an individually perceived treatment of a given individual, as compared with the others, following the principle of equality [39]. Adams differentiates between two types of fairness: distributive and procedural. The first one is expressed in a way the individual is treated in relation to the results accomplished; it is fair to treat employees accomplishing the same results equally and rewarding the best ones. Procedural fairness is related to the evaluation of the level of fairness of the incentive scheme, the system of evaluation and promotion and the related criteria, parameters and procedures applied [43]. Investigating the justice theory, Tyler and Bies [44] defined five factors affecting the procedural fairness evaluation: considering the employee's point of view, suppressing personal prejudice towards an employee, applying the same criteria to different employees, providing the employees with fast feedback on the results, evaluations and decisions taken in relation to work and explaining the decisions taken to the employees.

Intentions considered as goals, "consciously desired states" [45], satisfying the needs of the employee, as an important source of motivation, were indicated by E. Locke in 1968 [46]. The theory focuses not so much on the process but on the impact of the goals on behaviour [45]. The manager, determining the goals for the subordinates, should be able to influence their behaviour $[8,46]$.

The accomplishments of the individual at work depend on the interaction and the support of the specific effort, support of the organization and individual capacities and personality traits. Support from the organization stands for the actions of the company that are meant to help accomplish the goal. It can be, for example, providing the right personnel, infrastructure or means. Accomplishing satisfactory results, the individual receives external and internal rewards contributing to their satisfaction [47].

The cognitive evaluation theory by E. Deci and R. Ryan is a rarely discussed theory of motivation. It focuses on how extrinsic triggers can affect intrinsic triggers. It points to a crucial mechanism: extrinsic rewards, especially compensation, can be ineffective and decrease the interest in work and activity. According to that theory, each factor that enhances self-reliance and independence of the employee or their competences increases 
intrinsic motivation, and whatever has a limiting effect decreases it [26]. The basic factors that trigger a sense of a loss of control by an individual over their actions include, especially: incentive scheme making the amount and the kind of rewards depend on the task performance level; negative or control-like feedback; and autocratic management style [48].

Process theories are a very important indicator for the people developing incentive systems and for managers. Each of them provides a different value, from the guideline to inform the employee about the conditions of actions in a clear manner, through a clear rewarding system, all the way to the participation of an individual in creating the company goals. Those theories also provide a clear warning about abuse of some practices, e.g., compensation excessively dependent on performance or employees competing for a reward. The key to a well-operating enterprise is frequently adequate manager-employee communication [27].

An employee with passion and willingness to work is motivated to achieve results. The award, an example of external motivation, is used to raise the morality of the employee and their willingness to work. It is clear that employees work in return for their hard work and dedication, but how successful they are will depend on their motivation. Apart from rewards, other external factors motivate to work: a promotion at work, job security and salary increase. Motivated employees have a sense of belonging and loyalty to the organization and always work hard to be associated with the results of their work. Motivation affects employees as individuals to achieve as well as the ability to be innovative as they believe in themselves, which will benefit the organization to be successful [49].

A motivated employee is easy to maintain, thus saving the organization's finances related to replacing employees, and also encourages employees to always achieve more on their daily production as they feel secure in their work.

\subsubsection{Motivation Reinforcement Theories}

Reinforcement theories stem from an assumption that human behaviour is triggered by social environment stimuli. In practice, it means that, if a behaviour in the past led an individual to be appreciated or rewarded, the person will repeat it and the other way around; if a behaviour brings back unpleasant memories, the individual tries to avoid it [41]. Skinner claimed that people's behaviours can be modified compliant with the principle "stimulus_response-consequence-future behaviours" [18]. Skinner listed four behaviour modification techniques: positive reinforcement, learning to avoid, suppressing and punishment (negative reinforcement) [40].

The social learning theory was developed by A. Bandura based on the reinforcement theory and the goal-setting theory. The author assumed that behaviours are conditioned by personal experience and the observation of the environment [50]. The grounds for the theory were the results of an experiment performed in three isolated-from-one-another groups of children aged three to six. Each of the groups was shown a different version of a movie presenting aggressive behaviours of adults towards toys. In the first movie, an adult was rewarded for his behaviour and in the second one punished, while in the third one, no consequences of the behaviour were demonstrated. The next stage of the study was to evaluate the behaviour of children towards toys. The group watching a movie where the adult was punished for aggression showed definitely less aggression than the children watching a movie with an adult who was rewarded for his aggression. The level of aggression of the children watching a movie in which the consequences were not demonstrated was very similar to the level of the children watching the second version of the movie $[51,52]$.

The process of learning through observation starts with a selection of models and observing the specific behaviour consequences. The next stage is to remember the behaviours and transform them to become their own. The third stage is reinforcement. Repeating the behaviours for the selected model, we learn faster than with trial and error. Behaviour that works gets approved [51]. 
Reinforcement theories point to the importance of the environment. They assume that some individuals behave the way they have learnt in the past and based on what behaviours they associate with pleasure and what behaviours with negative effects. Managers should learn how to effectively affect the attitudes and behaviours of the employees. It is not about changing the employee; it is important and more effective to model the employee's behaviour. Here, praise comes in handy. It is, at the same time, the cheapest and the simplest way of reinforcing positive behaviours [25].

\subsection{Essence and Specific Nature of Network Marketing}

As reported in literature, network marketing, is known otherwise as MLM (MultiLevel Marketing, Network Marketing). This distribution method in Poland is known as the business of the 21st century. To put it in a nutshell, Multi-Level Marketing can be defined as one of the methods to launch products on the market. The method allows for the payment of commission on product turnover to all the network distributors engaged [52].

Trying to understand what network marketing is, its key definitions must be quoted. MLM is to hand over the product or service from manufacturer or service provider to the consumer. It is a term referring to the system of compensation for the persons who make the product or service delivered [53], or MLM is a way of selling products directly to the consumer through a network of independent distributors, built as successive sponsorship, in which compensation consists of the profit margin from the retail and wholesale sale and a bonus awarded for the turnover of the group built by a given distributor $[54,55]$.

The MLM system, as a product distribution method, was created to increase the scope and the level of distribution of products and services. Enterprises decide to apply the business model due to lowered advertisement costs and a lack of middlemen. The money saved can be allocated to compensations for the persons involved in distribution, applying innovative incentive schemes and compensation plans.

The first enterprises giving up a traditional form of sale and proposing a higher-quality product to the customer, at a lower price, thanks to eliminating expensive advertising and middlemen, emerged at the end of the 19th century in the United States. However, before the direct-sale sector conquered the neighbouring markets, there was established, among them, a group of distributors whose earnings came not only from the sale of products but also from building its own distribution network [55].

It is hard to understand the essence of network marketing without defining the term of direct sale. According to the definition by the Polish Association of Direct Sale, direct sale stands for offering goods and services directly to the consumers, through individual contacts, usually at the customer's home, at the workplace or in other places, outside the regular retail sale locations. It is a form of retail sale outside chain stores [56].

A comparison of economic activity in terms of network marketing with direct sale suggests that the key difference is business philosophy. The idea of direct sale is the sale of products and services without a traditional distribution channel. As for Multi-Level Marketing, it involves not only a personal sale of products and services but also developing one's own sales network [1]. Figure 1 presents a comparison of those two forms of activity.

Those activities mostly differ in income sources. As for direct sale, the distributor generates profits only from their own turnover, whereas, in Multi-Level Marketing, the entrepreneur gains profits not only from their own turnover but mostly from the turnover generated by their group-the so-called passive income.

In the market economy, there operate two kinds of income. Figure 2 presents a diagram of linear income generated in the process of an exchange of time for money, compliant with [57]:

$$
T I M E=M O N E Y
$$




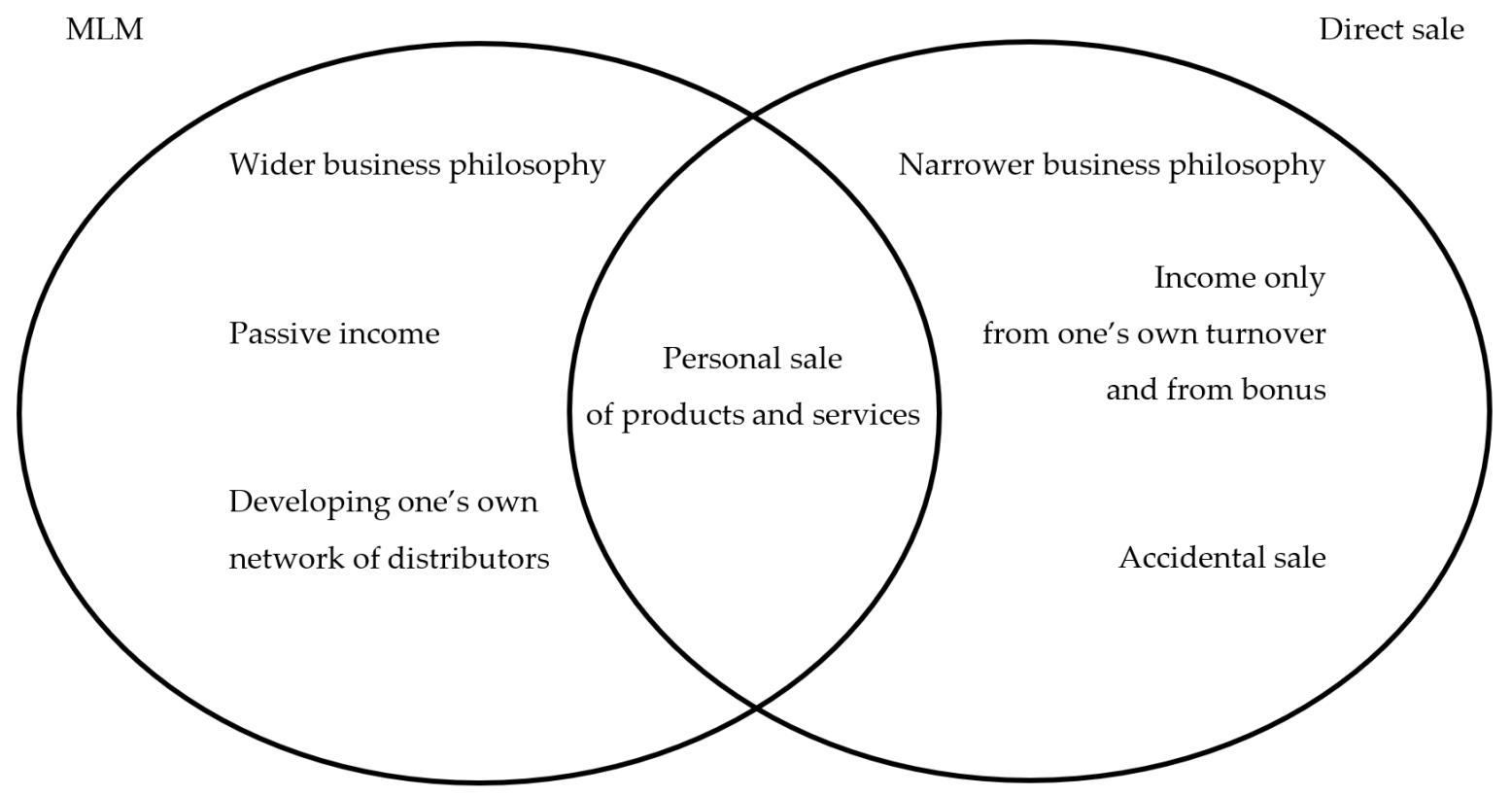

Figure 1. Comparison of activity as part of MLM with direct sale activity. Source: [1].

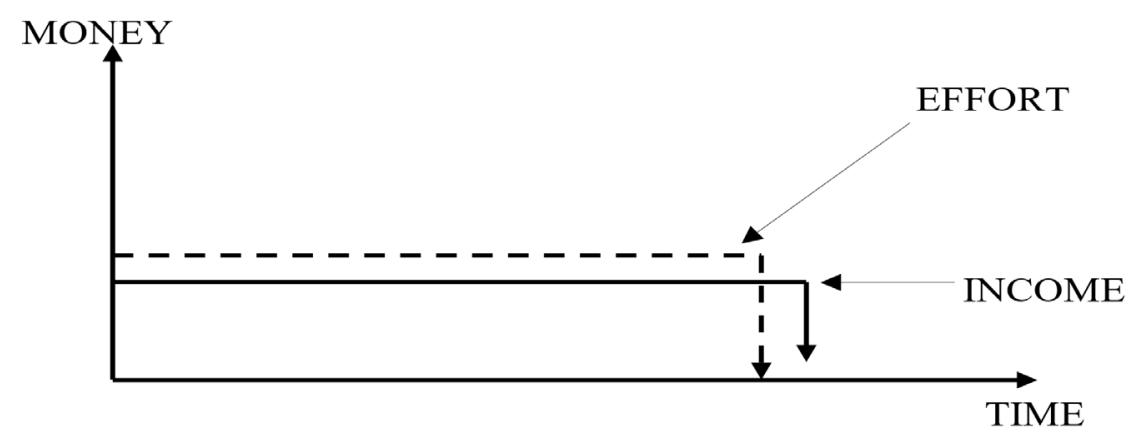

Figure 2. Linear income diagram. Source: [48].

As long as the individual is engaged in the operation of the enterprise and devotes time to work, they receive their compensation. When their effort stops, compensation also stops. The key to financial security or the so-called financial freedom is receiving the so-called passive income; every month, the money is credited into the account of the individual, irrespective of the time worked [58]. That relationship is demonstrated in Figure 3.

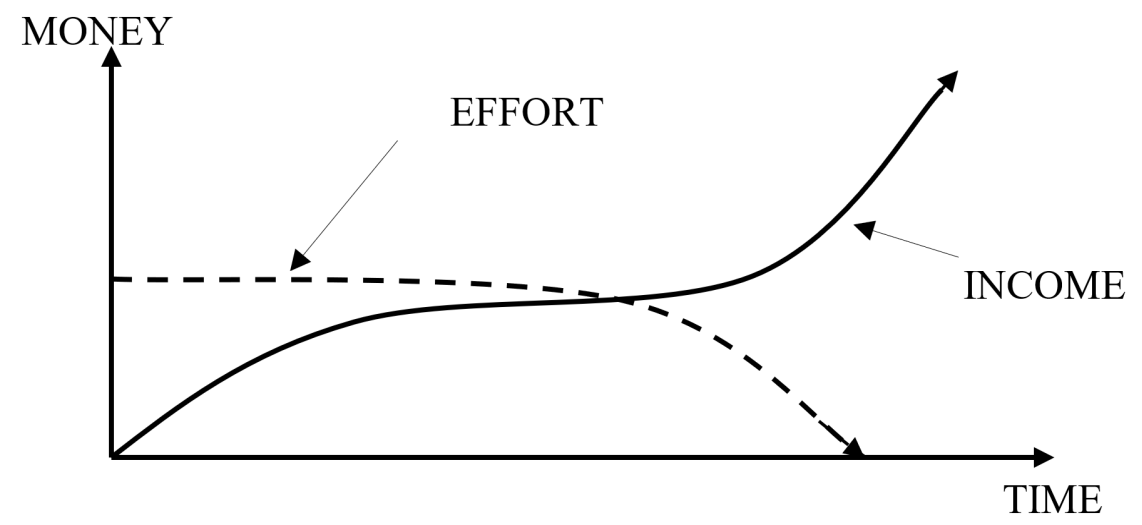

Figure 3. Passive income diagram. Source: [58]. 
As for passive income building, at the beginning of the activity, more effort must be made. One's own income increases gradually. After some time, the involvement of the individual decreases; however, it does not affect the amount of the income generated.

Network marketing is one of the least understood economic sectors. From the very beginning, enterprises based on that business model used to face a negative opinion and criticism and even resistance from society due to a lack of understanding of their ideas [1]. In the 1950s and the 1960s, it used to be compared with American pyramid schemes responsible for the naïve citizens losing millions of dollars. Their position improved only at the end of the 1970s when, in the United States, a court judgment was passed in favour of Amway [56].

Network marketing is still facing many accusations of being a pyramid scheme. It usually comes from the fact that the organizational structures of MLM enterprises do remind a pyramid-like shape. One must note, however, that MLM is not a pyramid scheme but an organization with, just like every other enterprise, a pyramid-like structure [1].

A pyramid scheme, determined with the Ponzi scheme, is a system of avalanche sale, which is an example of illegal activity. According to the definition by the Polish Financial Supervision Authority, the institution supervising the financial market in Poland, pyramid is a clear form, and it stands for the structure in which the profit of a given person depends on the payments made by the persons found lower in the structure. The operation of the pyramid involves promising profits to the participants, mostly for recruiting new persons to participate in the structure rather than for rendering real investment services [59].

The authors of pyramid schemes frequently impersonate legal and well-recognized MLM firms, thus tarnishing their reputation. Operating as part of network marketing, as opposed to the pyramid scheme, is not forbidden by law [1].

Today most people earn a living with one of the four methods. American multimillionaire and investor Kiyosaki, based on it, has created a money flow model which he referred to as a cash flow quadrant [50]. The model is presented in Figure 4.

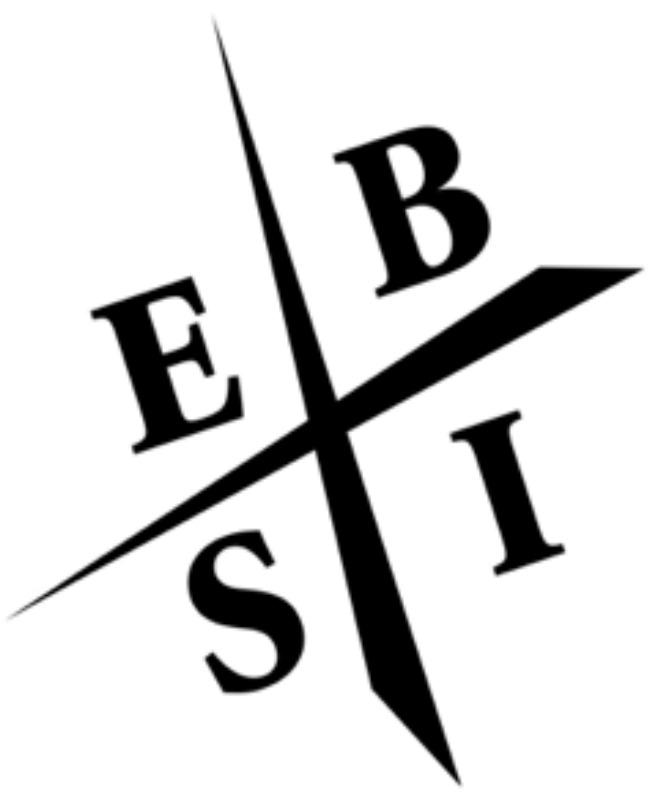

Figure 4. Cash flow quadrant. Source: [50].

Quadrant E stands for a regular job. Most people in society do not leave that quadrant for their entire lives. It is conditioned by the education system and the economic situation which make us believe that it is the best possible form of making money. In that position, the person spends $8-10 \mathrm{~h}$ a day and earns the national average. Quadrant $\mathrm{S}$ means selfemployment or the owner of a small enterprise. Many people develop their qualifications and decide to move to that quadrant driven by the need for greater freedom and deciding 
about their own life. Thanks to greater engagement, those persons become the best in their enterprise, and thus their presence there becomes obligatory. They spend $16-24 \mathrm{~h}$ a day at work, and they make about three times the national average. In quadrant $\mathrm{B}$, people start creating large enterprises. The difference between quadrants $B$ and $S$ is that in the case of self-employment, the owner of a small enterprise works for their business, and in quadrant $B$, it is the business that earns money for the owner. The enterprise operates when the owner is not present, generating money continuously. The last quadrant, namely quadrant I, stands for investments. Entrepreneurs invest in many different investment projects, e.g., in immovable property. The money invested works for them, generating a passive income [50].

Network marketing falls within quadrant B, and, as such, it is referred to as the 21st-century business [59]. The operation as part of the MLM system is attractive for persons representing each market segment, irrespective of their gender, age, educational background or the income generated. Thanks to the technology solutions available, which keep developing, as well as low initial costs and flexible working time, it attracts the interest of many women who can thus combine their professional life with the housework and children upbringing. Flexitime also facilitates combining network marketing with a regular job, especially at the beginning, when the income generated is still relatively low. Table 4 provides a comparison of a regular job with a network marketing job.

Table 4. Differences between a regular job and a network marketing job.

\begin{tabular}{cc}
\hline \multicolumn{1}{c}{ A Regular Job } & Network Marketing Job \\
\hline $\begin{array}{c}\text { Fixed compensation + a pay } \\
\text { increase possibility }\end{array}$ & No financial limitations \\
\hline The boss & No time and space limitations \\
\hline Accurately specified working time and place & The mentor \\
\hline $\begin{array}{c}\text { Specific scope of responsibilities and related } \\
\text { control and supervision system }\end{array}$ & No scope of obligations and no related control \\
\hline $\begin{array}{c}\text { A possibility of blaming others for one's } \\
\text { lack of promotion }\end{array}$ & No such possibility \\
\hline $\begin{array}{c}\text { In general, no possibility to earn more than } \\
\text { others higher up in the company structure }\end{array}$ & The situation actually desired \\
\hline $\begin{array}{c}\text { A possibility to make a career } \\
\text { "by knowing someone” }\end{array}$ & No such possibility \\
\hline $\begin{array}{c}\text { In general, a modest non-financial } \\
\text { incentive system }\end{array}$ & Very attractive non-financial incentive system \\
\hline Source: [60].
\end{tabular}

Multi-Level Marketing is a fair business. The results are accomplished only by the person who works enough. Diligent and regular work can bear fruit in a form of generating a high passive income.

\section{FM World Enterprise(s) Characteristics}

\subsection{Origins of the Enterprise}

FM World was established in September 2004 by Trawiński [61]. The company has Polish roots with headquarters in Wrocław. Initially, it was known under the name FM Group Polska; however, over a few years, the company developed considerably and, in 2007, it was transformed into FM Group World. In 2016, it transformed into FM World Distribution, since then distributing the products to every part of the world in six continents [62]. The way the company developed over years is demonstrated in Figure 5. 


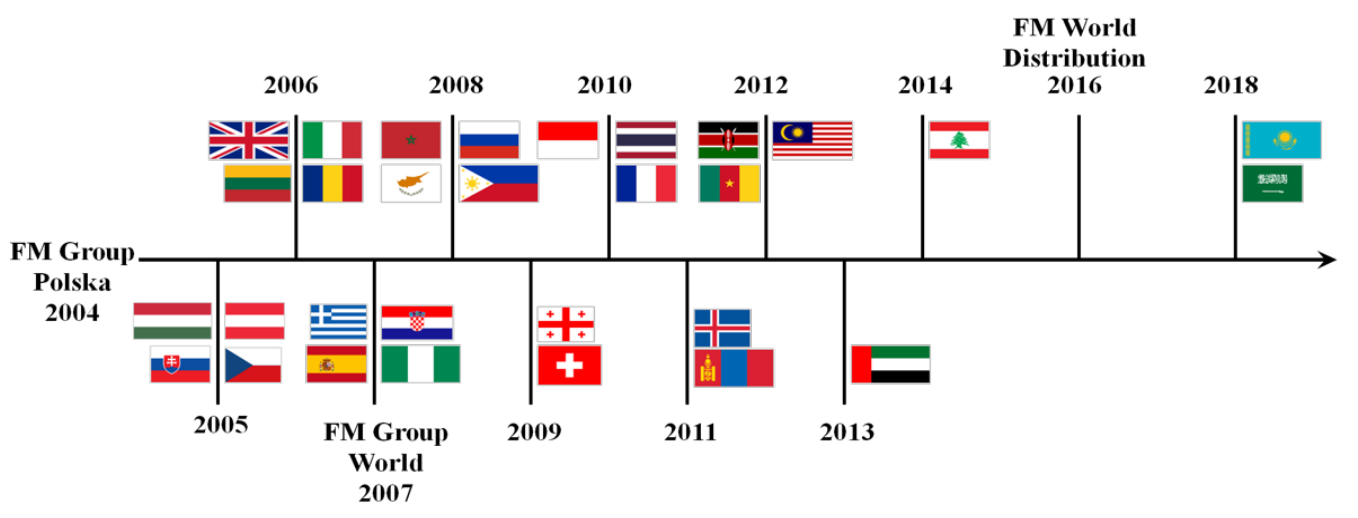

Figure 5. FM World development in 2004-2018. Source: [63].

The company was launched in Poland, and then it expanded to the neighbouring countries of Europe. The first foreign branch was established in 2005 in the Czech Republic. At present, it operates branches in 46 countries and delivers its products to 93 countries globally, which makes it a global company.

From the start of the operation, FM World was cooperating with, established in 1995, PERFAND, the owner of which is the father of the founder of FM World, Trawiński. The company produces high-quality women's and men's perfumes that the company, FM World, started its career from [57]. The next partner of FM World is a German enterprise, DROM Fragrances International, headquartered in Munich. The company enjoys many-year experience as it was established in 1911 by Bruno Storp. DROM Fragrances International is one of the biggest producers of fragrance extracts; it cooperates with many cosmetic brands known across the world, especially Hugo Boss and Chanel [64].

\subsection{Enterprise Product Offer}

FM World distributors are offered a number of universal good-quality everyday products and services. They are addressed to a large group of consumers across the world, irrespective of their age, gender, education or place of residence [65-67]. The company offers products in eight branches: perfumes, white cosmetics, colour cosmetics, coffee and tea, diet supplements, household chemicals, telecommunications services [68] and the Internet and accounting services [69].

The company's first product was perfumes. Currently, FM World's offer covers 100 various women's fragrances divided into five fragrance groups: flower, citrus, oriental, wood and chypre. The fragrances of the perfumes for male consumers are half as many; they come in six fragrance groups: flower, chypre, oriental, wood, fougere and citrus. The company also offers nine unisex fragrances. The perfumes have been divided into seven categories which differ from one another in fragrance percentage, price range and packaging. The following collections have been created: Pure, Pure Royal, Pheromone, Intense, Classic Collection, Luxury Collection and Utique [70]. Some fragrances also provide their equivalents as fragranced balms, shower gels, hair perfumes and antiperspirants, as well as the fragrances-for-home line Pure Home [70].

\subsection{Compensation Scheme}

FM World operates under network marketing, which provides the person starting cooperation with complete freedom in selecting business partners and working hours, which is not guaranteed when having a regular job.

When getting registered in FM World, a business partner can choose between two options [62]:

- Customer/consumer: a person buying products only for their own needs and the needs of the closest family, at partner-like prices and with access to promotion, however, without the possibility of building a sales network; 
- User: a person buying products at a partner-like price, with access to promotion and with a possibility of creating own consumer network.

The user status allows the business partner to earn money in two ways. First of all, the user can buy products at wholesale prices, thus saving on recurring expenses. They can also get engaged in distribution, namely the sale of articles and services to family and friends. By placing an order, the distributor purchases a product at a partner price and thus receives the right to sell it further at the catalogue price, earning from the price difference, the so-called profit margin, which accounts for about $30 \%$ of the market price. Table 5 presents a sample direct profit generated from the sales of products with a profit margin.

Table 5. Sample direct profit generated from the sales of products with a profit margin.

\begin{tabular}{cccc}
\hline FM World Product & Catalogue Price & Partner Price & Margin \\
\hline Pure Royal 199 men's perfumes & PLN 89.00 & PLN 59.00 & PLN 30.00 \\
Beta-Glucan Active Moisturising & PLN 49.90 & PLN 34.93 & PLN 14.97 \\
Body Balm & PLN 299.00 & PLN 200.00 & PLN 99.00 \\
Nutricode vitamin set for her & PLN 59.90 & PLN 41.93 & PLN 17.97 \\
Aurile Energy coffee & & Total & PLN 161.94 \\
\hline
\end{tabular}

Source: [71,72].

The other possibility of earning money in FM World is creating one's own business by building a network of users, namely bringing new persons who want to start active cooperation with the company and make money on the company's global turnover. The amount of the money earned by a business partner depends on their engagement in developing a network of consumers. The company awards commission neither in a form of commercial discount nor in a form of compensation for joining the FM World Club only, nor for registering new persons only. Network marketing is a business based on sales and the amount of commission depends, e.g., on the point turnover generated with the entire sales network [73].

By purchasing a product offered by FM World, the buyer is awarded points for it. The points are accumulated throughout the month, and they provide the grounds for being qualified at a given level of effectiveness from $0 \%$ to $21 \%$. The commission received is the sum of the turnover received by the distributor and the distributor's group over one calendar month; points are earned from the beginning in the successive month. Table 6 presents the principles of getting qualified for the successive level of effectiveness in the First Marketing Plan.

Table 6. Details of the FM World First Marketing Plan.

\begin{tabular}{cccc}
\hline Title & Level of Effectiveness & Group's Point Turnover & Compensation \\
\hline \multirow{2}{*}{ Magnolia } & $3 \%$ & $300-1199.99$ & From PLN 9 \\
& $6 \%$ & $1200-3599.99$ & From PLN 50 \\
& $9 \%$ & $3600-7199.99$ & From PLN 150 \\
\hline \multirow{2}{*}{ Silver Magnolia } & $12 \%$ & $7200-11,999.99$ & From PLN 400 \\
& $15 \%$ & $12,000-20,399.99$ & From PLN 800 \\
Golden Magnolia & $18 \%$ & $20,400-29,999.99$ & From PLN 1600 \\
\hline Source: [73]. & $21 \%$ & From 30,000 and higher & From PLN 3000 \\
\hline
\end{tabular}

An important technical aspect is how to build a network of distributors. In Multi-Level Marketing, the idea is not about entering the highest number of people as the company does not pay a commission on the number of people invited to cooperation but on the total turnover of the structure and on the percentage difference between the so-called sponsor and the persons in their network. For the network to operate adequately, it is enough to register three to five people who will also get engaged and who will create their own networks of distributors. 
Sample calculations of the leader's commission are as follows:

A given structure is built on six levels A, B, C, D, E and F, where level A receives 12,000 group points, thus reaching a $15 \%$ effectiveness level. Level $B$ is awarded 7900 group points and reaches $12 \%$. Level $C$ accumulates 7200 group points, which also makes it reach a $12 \%$ level. Levels D, E and F accomplish a 9\% level by accumulating 5300, 5100 and 5000 group points, respectively. The leader, thanks to the accumulated group points and personal purchase points (100 points), accomplishes 42,600 group points and thus reaches a $21 \%$ effectiveness. To calculate the leader's commission, the effectiveness of respective levels below the leader must be deducted from the leader's level. The differences must be multiplied by the group points accumulated by distributors of a given structure.

Personal purchase: 100 points $\times 21 \%=$ PLN 21
A: $12,000 \times(21-15 \%)=$ PLN 720
B: $7900 \times(21-12 \%)=$ PLN 711
C: $7200 \times(21-12 \%)=$ PLN 648
D: $5300 \times(21-9 \%)=$ PLN 636
E: $5100 \times(21-9 \%)=$ PLN 612
F: $5000 \times(21-9 \%)=$ PLN 600

In total, the compensation amounts to PLN 3948.

The next stage of a career path in FM World is the Second Marketing Plan. It creates a possibility to get even higher compensation.

\subsection{Incentive Schemes}

FM World offers a number of promotions and incentive schemes. Their purpose is to provide knowledge and tools as well as to motivate the business partner to make an effort to care for their structure to ensure higher profits both for them and for the company [74].

Promotions addressed to all the business partners registered in the company include a "happy hour", a promo of the day, a weekend promotion, a promotion of the week and a monthly promotion. The first four promotions most often involve a price discount or an increase in points of specific products, while the promotion of the month allows each business partner to place an order with the adequate point value for purchasing an additional product package at the price of PLN 1.23. There are two different product sets to choose from, with eleven variants in each, depending on the order value [75].

"Package with a surprise" is a welcome promotion for newly registered distributors. Each new business partner who, within 14 days after the registration date, places an order corresponding to the value of minimum 100 personal points, receives a surprise gift of the catalogue value of about PLN 30 and a free order delivery [76].

"For a good start" is an incentive scheme to facilitate new business partners getting to know a wider range of products. The promotion is divided into three stages, each for one month, as demonstrated in Table 7 . The first stage starts with a distributor registration in the company [77].

Table 7. Principles of participation in "For a good start" incentive scheme.

\begin{tabular}{cccc}
\hline Stage & Points & Products & Product Value \\
\hline I & 250 & Smart\&Clean products & PLN 38.64 (for PLN 1) \\
II & 250 & Care and makeup cosmetics & PLN 49.80 (for PLN 3) \\
III & 250 & Perfumes & PLN 85.80 (for PLN 5) \\
\hline
\end{tabular}

Source: [77].

"Active Recruitment" scheme is addressed to the leaders who recruit new active business partners. If in the first month from registration a new person places the first order with a minimal point value, as given in Table 8 , the recruiting person will receive an additional compensation/commercial discount dependent on the point turnover of the new distributor [77]. 
Table 8. "Active Recruitment" incentive scheme details.

\begin{tabular}{cc}
\hline $\begin{array}{c}\text { Personal Points Generated by a New } \\
\text { Business Partner }\end{array}$ & $\begin{array}{c}\text { Additional Remuneration/Commercial } \\
\text { Discount for the Recruiting Person }\end{array}$ \\
\hline 150-299.99 points & PLN 15 \\
300-599.99 points & PLN 25 \\
Above 600 & PLN 55 \\
\hline
\end{tabular}

Source: [77].

"Quarterly Bonus" is an incentive scheme addressed to distributors from $0 \%$ to $18 \%$. If a business partner in each of the three successive months does shopping for minimum 250 points, they receive an additional quarterly discount accounting for $25 \%$ of the total commercial discount awarded for three successive months in which the conditions were met [77].

"Welcome home" is a scheme to motivate distributors to build a model structure where $21 \%$ is made of six levels. For each month in which the model structure is built and the additional conditions, including personal and group points as well as point turnover of the base month, are satisfied, the company pays the distributors the amount of PLN 2000 to the distributors for their own expenses. The scheme can be used twice at each level of effectiveness from 9\% to Amaranth Orchid [68].

One of the most attractive incentive schemes is "Trip for Knowledge", addressed to the distributors at the level of effectiveness from $0 \%$ to $18 \%$; it guarantees to its laureates training in the most beautiful parts of the world. The business partner gets qualified for such event if, in the base month, they fell in the range from $0 \%$ to $18 \%$. If they reach the target level and maintain it for the successive two accounting months, they receive one or two trips depending on the level they were promoted to. The principles of being qualified for the training are provided in Table 9. City Break is a 3-4-day trip. Participants of previous editions visited, e.g., London, Barcelona and Prague. LUX is a 5-7-day training. The laureates have so far visited Majorca, Kenya, Jordan and Tenerife and enjoyed a cruise in the Mediterranean Sea [78-80].

Table 9. "Trip for Knowledge" incentive scheme participation conditions.

\begin{tabular}{ccc}
\hline Level in the Base Month & Target Level & Training \\
\hline $0-9 \%$ & $15 \%$ & City Break \\
$12 \%$ & $18 \%$ & LUX \\
$15-18 \%$ & $21 \%$ & LUX \\
\hline
\end{tabular}

Source: [77].

FM World wants to reward its best leaders, and thus it gives them an opportunity to participate in the company's anniversary celebrations held in the most luxurious global destinations, e.g., the Maldives or Singapore. The company covers all the business partner's flight and stay costs. To be invited, the leaders who, in the base month, found themselves at any level of the First Marketing Plan or at the Pearl Orchid Level, over the qualification time [77]:

- Must at least five times repeat the level of Pearl Orchid or higher;

- Once they reach the Pearl Orchid level for the first time, cannot fall down more than one level, not lower than to the Golden Magnolia level;

- Must have an active agreement of participation in the "Road to Success" incentive programme, a luxurious car programme.

"Bull's eye" programme is addressed to Pearl and Amaranth Orchid leaders. If a distributor manages to maintain the point turnover of their structure of the base month and receive at least 100 personal points for each branch that has accomplished the level of effectiveness of minimum $12 \%$, he or she will receive an additional compensation every month, see Table 10 . 
Table 10. "Bull's eye" incentive programme details.

\begin{tabular}{cc}
\hline Level of Effectiveness of Branch in the Structure & Amount of Additional Compensation \\
\hline Orchid & PLN 800 \\
$21 \%$ & PLN 600 \\
$18 \%$ & PLN 400 \\
$15 \%$ & PLN 300 \\
$12 \%$ & PLN 200 \\
\hline
\end{tabular}

Source: [77].

The last incentive programmes offered by the company are "Carmotion" and "Road to success", a luxurious car programme. As part of the first programme, a distributor can receive an additional compensation which will help the payment of the leasing instalment or the payment of long-term car rental, and if they already have their own car, the commission will help cover the depreciation costs. "Road to Success" is a programme offering, to the business partners above Golden Magnolia, an additional compensation for the payment of leasing instalment of the car of one of the three luxurious makes: Mercedes-Benz, Mazda and Porsche. The distributor who repeats the level of effectiveness three times in successive months gets qualified. Additionally, thanks to the agreement signed with the dealers of those car makes, the distributor can collect the car in any dream colour, with dream accessories and with a substantial discount, as compared with the car market price. For example, for Mercedes-Benz, it can be even $23 \%$ of the price. Table 11 presents the principles of qualification at respective levels and a sample amount of additional compensation [68].

Table 11. "Road to Success" programme qualification principles.

\begin{tabular}{ccccc}
\hline Level & $\begin{array}{c}\text { Points in FM } \\
\text { World Polska }\end{array}$ & Personal Points & Additional & Compensation (Gross) \\
\hline Golden Magnolia & 30,000 & 100 & $\begin{array}{c}\text { Monthly compensation during } \\
\text { qualification should be at least PLN 2500 } \\
\text { Reaching the Golden Magnolia level at } \\
\text { least three times }\end{array}$ & PLN 1300 \\
Pearl Orchid & 40,000 & 100 & $\begin{array}{c}3 \text { branches at least 20,000 points each } \\
\text { in Poland }\end{array}$ & PLN 2200 \\
Amaranth Orchid & 100,000 & 100 & $\begin{array}{c}\text { 3 branches at least minimum 20,000 } \\
\text { points each in Poland }\end{array}$ & PLN 3150 \\
Golden Orchid & 200,000 & 100 & 3 branches minimum 20,000 points each & PLN 6300 \\
in Poland
\end{tabular}

Source: [68].

An incentive system is a system of interconnected and supporting-one-another incentive means which, creating a coherent whole, are to serve the execution of the mission, vision, strategy and accomplishing the goals of the company [44]. Dedicated by FM World, to business partners, it is understandable and oriented at the needs of individuals.

\subsection{SWOT Analysis}

For the adequate development and operation of the company, the analysis of its market position is very important [80]. For that purpose, the SWOT strategic analysis for a comprehensive evaluation of the company's business environment and its internal analysis is most frequently applied. The term SWOT is an acronym of "Strengths", "Weaknesses", "Opportunities" and "Threats" [81]. Table 12 presents the SWOT analysis performed for FM World.

FM World is very strongly rooted in global network marketing. Thanks to the good quality, the products and services enjoy a good reputation and win many awards, not only for the product offer but also for the compensation plan and the organization management method. The company keeps developing; every year, it launches new products, thus using more and more innovative technologies so far not used by competitors. The company uses 
its opportunities, e.g., cooperation with dietitians or beauty professionals. The company is open to Internet communication development, which can be seen from its presence on social media.

Table 12. SWOT model developed for FM World.

\begin{tabular}{|c|c|c|}
\hline & Positive & Negative \\
\hline $\begin{array}{c}\text { Internal } \\
\text { (organization features) }\end{array}$ & $\begin{array}{l}\text { Strengths } \\
\text { - } \quad \text { Strong global presence; } \\
\text { - } \quad \text { Many awards and honours; } \\
\text { - } \quad \text { A wide range of products; } \\
\text { - } \quad \text { A wide consumer range; } \\
\text { - } \quad \text { Simple, innovative compensation plan; } \\
\text { - } \quad \text { Modern distribution method; } \\
\text { - } \quad \text { State-of-the-art technologies application. }\end{array}$ & $\begin{array}{l}\text { Weaknesses } \\
\text { - } \quad \text { Limited product availability; } \\
\text { - } \quad \text { High price of some products; } \\
\text { - } \quad \text { No traditional advertisement form; } \\
\text { - } \quad \text { Negative opinion of the society about the } \\
\text { business model applied. }\end{array}$ \\
\hline $\begin{array}{c}\text { External } \\
\text { (environment features) }\end{array}$ & $\begin{array}{l}\text { Opportunities } \\
\text { - } \quad \text { Increasing product availability; } \\
\text { - } \quad \text { tarting cooperation with health and } \\
\text { beauty experts; } \\
\text { - } \quad \text { Internet communication development; } \\
\text { - Increasing interest in starting own enterprise } \\
\text { by people at every age; } \\
\text { - Increasing eco-awareness in the society; } \\
\text { Ongoing sector development. }\end{array}$ & $\begin{array}{l}\text { Threats } \\
\text { - Domestic and international competition } \\
\text { development; } \\
\text { - Unfavourable demographic changes; } \\
\text { - Increased product composition consumer } \\
\text { awareness; } \\
\text { - } \quad \text { Low society affluence; } \\
\text { Change of consumer preferences and tastes. }\end{array}$ \\
\hline
\end{tabular}

Source: Own study.

\section{Aim, Hypotheses, Material and Methods}

The key objective of the paper is to present a compensation plan and the possibilities resulting from cooperation with FM World operating based on network marketing.

The paper provides two hypotheses:

- There is a positive relationship between the number of FM World distributors planning further cooperation with it in the future and the period of its cooperation so far.

- Most of the surveyed distributors of FM World assess the effectiveness of incentive programmes at a very good level.

For the purpose of this paper, a study was performed with FM World distributors. The basic criterion affecting the sample selection was belonging to Rentierzy.FM group including some business partners in Poland and globally.

The research method involved a diagnostic survey. The respondents were selected with a snowball method involving a nonrandomized selection of the sample by participants being recruited by other participants [75].

The study was performed in June 2019. The research tool used to collect the answers was an online survey questionnaire; the respondents answered fifteen questions.

The study group included FM World distributors (the characteristics of FM World are presented in Section 3). The sample was selected on purpose, and it is not a representative sample as it does not cover the opinions of all the registered business partners. Table 13 provides the study group characteristics.

The sample included 107 persons: 44 women and 63 men, 16 to 65 years of age. The most numerous group included persons aged 21 to 26 and 27 to 35 . About $30 \%$ of the respondents cooperated with the company for less than one year; there were also respondents cooperating for more than 7 years. The earnings of more than half of the respondents were below PLN 5000, while the respondents with income ranging from PLN 5000 to 10,000 accounted for $29 \%$ of all the respondents. 
Table 13. Characteristics of the population under study.

\begin{tabular}{ccc}
\hline & $\mathbf{N}=\mathbf{1 0 7}$ & $\%$ \\
\hline Woman & Gender & \\
Man & 44 & $41.1 \%$ \\
& 63 & $58.9 \%$ \\
\hline 16-20 years of age & Age & \\
21-26 years of age & 18 & $16.8 \%$ \\
27-35 years of age & 44 & $41.1 \%$ \\
36-49 years of age & 34 & $31.8 \%$ \\
50 years of age and older & 9 & $8.4 \%$ \\
\hline & 2 & $1.9 \%$ \\
PLN 0-1000 & Monthly net income per household & \\
PLN 1001-2500 & 26 & $24.3 \%$ \\
PLN 2501-5000 & 14 & $13.1 \%$ \\
PLN 5001-10,000 & 24 & $22.4 \%$ \\
PLN 10,001-25,000 & 31 & $29 \%$ \\
PLN 25,001 and more & 9 & $8.4 \%$ \\
\hline
\end{tabular}

Source: Own study.

\section{Results}

\subsection{Factors Affecting an Interest in Network Marketing}

To provide more thorough characteristics of the group, the respondents were asked about how long they had been cooperating with the company and about the effectiveness level accomplished. The results are provided in Figures 6 and 7.

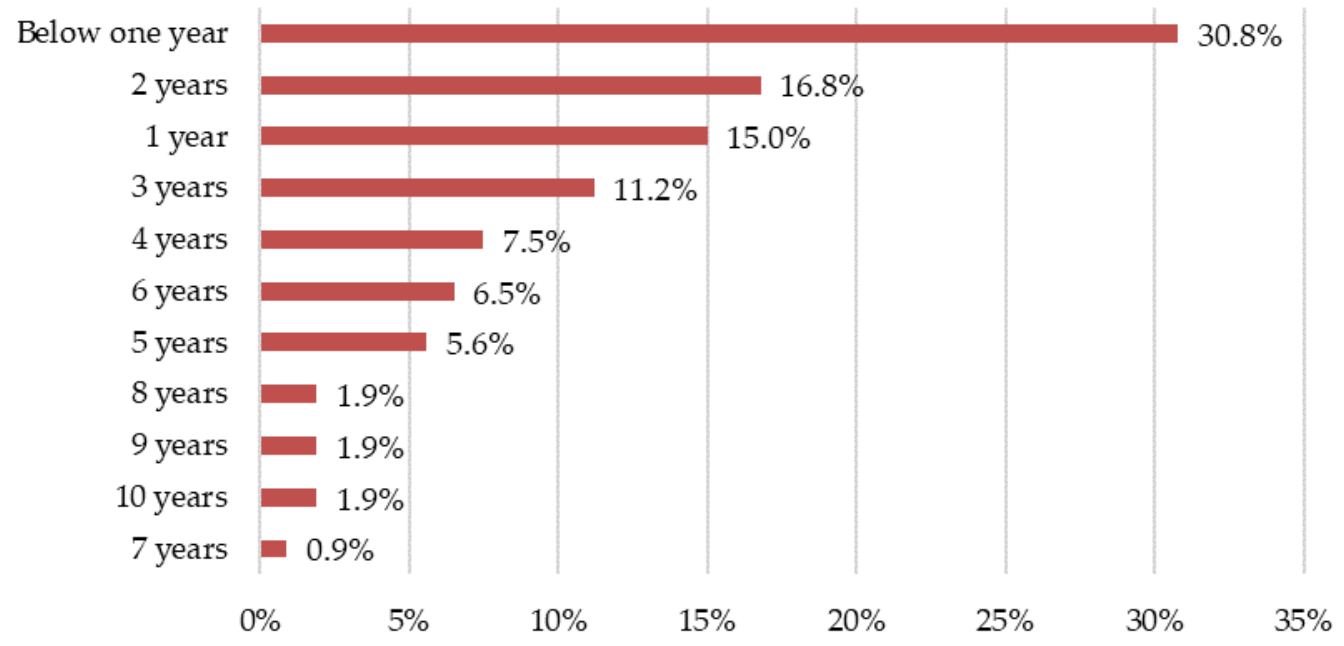

Figure 6. Period of cooperation with FM World (\%). Source: results of own study.

The study shows that almost $31 \%$ of the respondents had cooperated with the company for less than one year. The persons operating in the company for more than one year, however, not longer than 4 years, accounted for $50.5 \%$ of the study group. Nevertheless, the study also involved persons with more than 5-year cooperation, accounting for almost $20 \%$. The longest seniority indicated by the respondents was 10 years.

The next figure presents the levels of effectiveness of the distributors surveyed. The data demonstrate that their vast majority was found in the First Marketing Plan. In the lowest positions ( $0 \%$ to $9 \%$ ), there were found almost half $(46.9 \%)$ of the persons who participated in the survey. The persons from $12 \%$ to $21 \%$ accounted for $34.5 \%$ of all the respondents. The other $18.6 \%$ were persons from the Second Marketing Plan. 


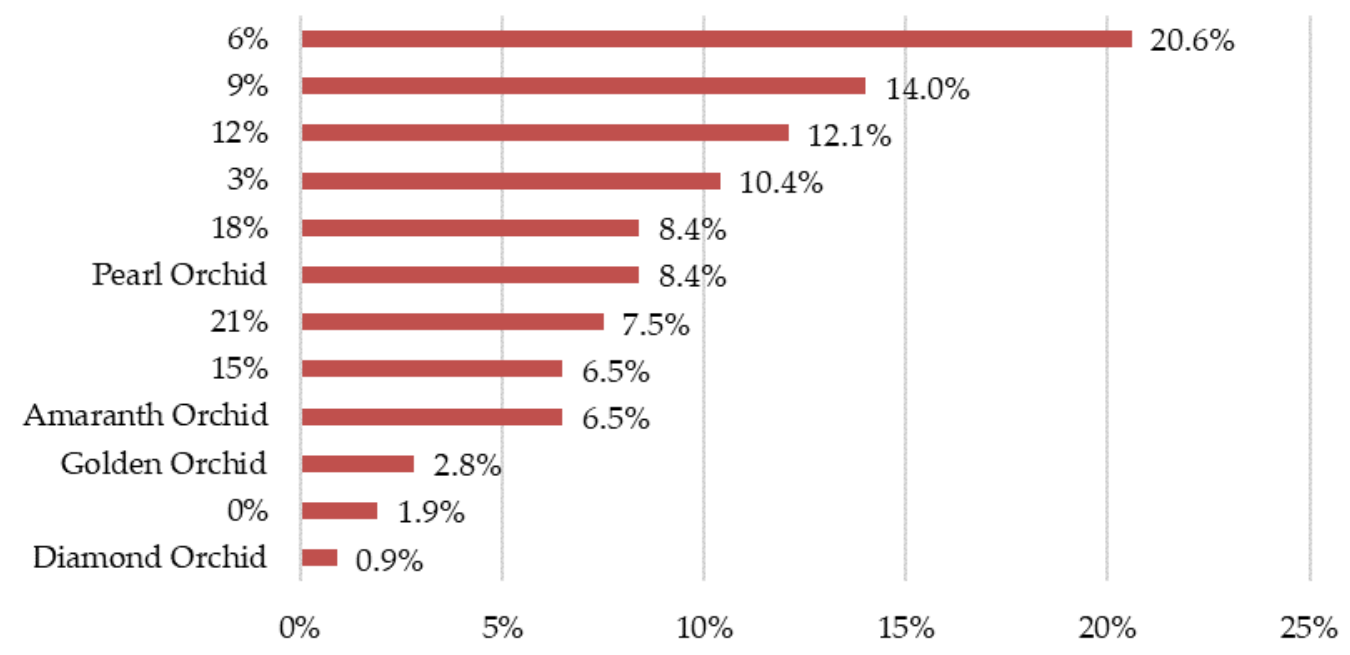

Figure 7. Level of effectiveness accomplished in FM World (\%). Source: results of own study.

Such data can result from, e.g., cooperation seniority. Figure 8 presents factors that affected the decision of the respondents on joining FM World.

Possibility of building one's income

Possibility of working with friends

Possibility of being one's own boss

Possibility of working from home

Vast incentive programme offer

Possibility of generating an extra income

Eagerness to learn more

Innovative compensation plan

Possibility of getting to know new people

Attractive training offer

Possibility of e-shopping

Polish company roots

The sector the company operates in

Possibility of buying at lower prices

Abundant product portfolio

Possibility of earning on profit margin$$
0 \%
$$

$\begin{array}{llllll}0 \% & 20 \% & 40 \% & 60 \% & 80 \% & 100 \%\end{array}$

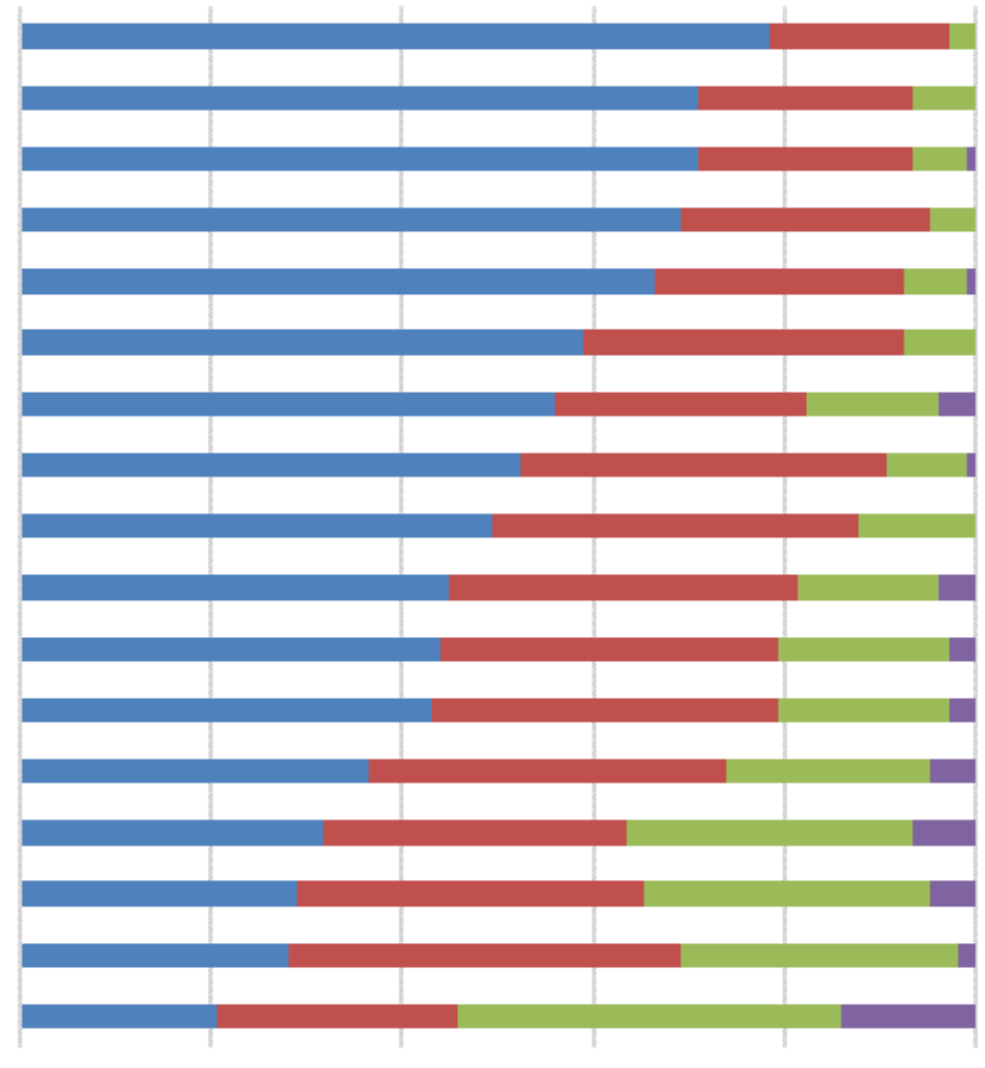

Very high impact

Quite low impact
Quite high impact

Very little impact/no impact

Figure 8. Factors determining the decisions on cooperation with FM World (\%). Source: results of own study. 
Figure 8 shows that the most important factor affecting the decision of the respondents to start cooperation with FM World was flexitime, with $78.5 \%$ of the respondents. The successive factors concerned the possibility of cooperation with friends and generating passive income (71\% each), an eagerness to be one's own boss $(69.2 \%)$ and the possibility of working from home $(66.4 \%)$. Nevertheless, an essential aspect for distributors was the possibility of earning money on profit margin $(14 \%)$ and the sector the company operates in (6.5\%). Figure 9 presents the most important aspects of the MLM sector operation.

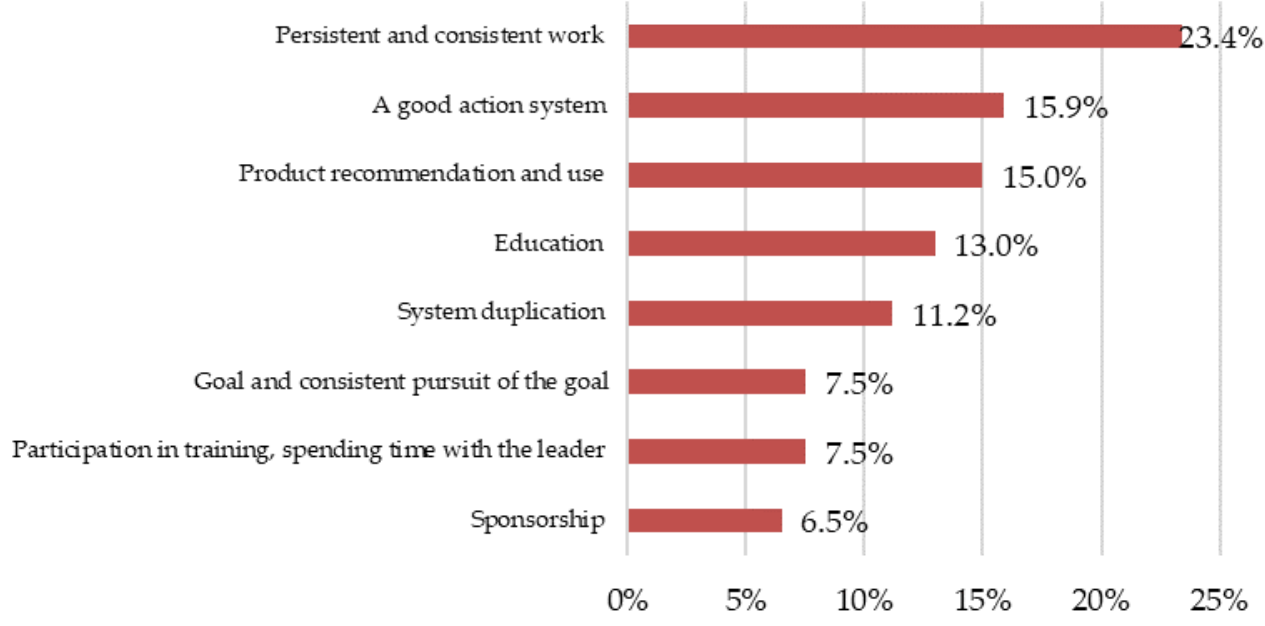

Figure 9. Key aspects of operation under network marketing (\%). Source: results of own study.

The most frequently selected aspect was persistent and consistent work (23.4\%). A good action system $(15.9 \%)$ and product recommendation and use $(15 \%)$ were also considered essential. The least common response was sponsorship (6.5\%).

\subsection{FM World Compensation Plan Effectiveness}

As for the compensation plan effectiveness, the respondents agreed: $99.1 \%$ of them were satisfied with it. Only one person was not satisfied with the way of earning income in cooperation with FM World. Figure 10 presents the compensation components in FM World.

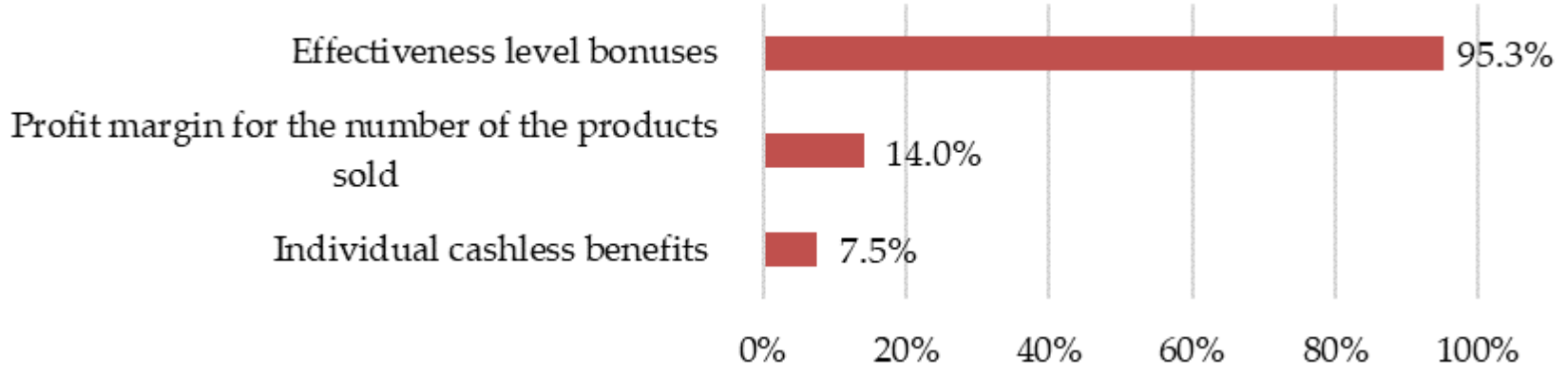

Figure 10. FM World compensation components (\%). The respondents could indicate more than 1 answer. Source: results of own study.

Almost the entire study group (95.3\%) answered that the FM World key compensation components are bonuses for accomplishing a specific effectiveness level. Additionally, the profit margin on the sales of products at catalogue price was pointed to by only $14 \%$ of the respondents, and $7 \%$ chose individual cashless benefits. Figure 11 presents the level of satisfaction with the income generated in cooperation with the company. 
I plan my future career with FM World.

Income earned in cooperation with FM World satisfies me completely.

Income earned in cooperation with FM World is the main one for me.

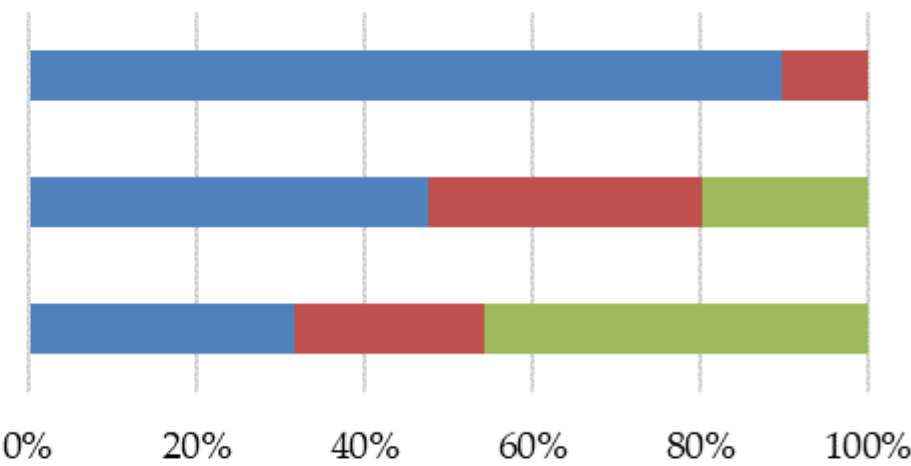

\section{I totally agree $\quad$ I do not know $\quad$ I do not agree at all}

Figure 11. Satisfaction with the income generated in FM World (\%). Source: results of own study.

The data presented in Figure 11 show that $90 \%$ of the respondents planned their future careers with FM World. The other 10\% could not specify yet if they wanted to cooperate long-term with FM World; those were the persons at the beginning of their operation. Only almost $50 \%$ of the respondents were satisfied with the income generated in cooperation with the enterprise, while $20 \%$ would like to earn more. Only for one-third of the persons taking part in the survey, that income was the only or the key source of income; for $46 \%$, it was an additional income.

\subsection{Incentive Programme Functions}

To help the distributors in developing the network of consumers, the company operates a number of incentive programmes. Figure 12 presents the evaluation of their effectiveness.

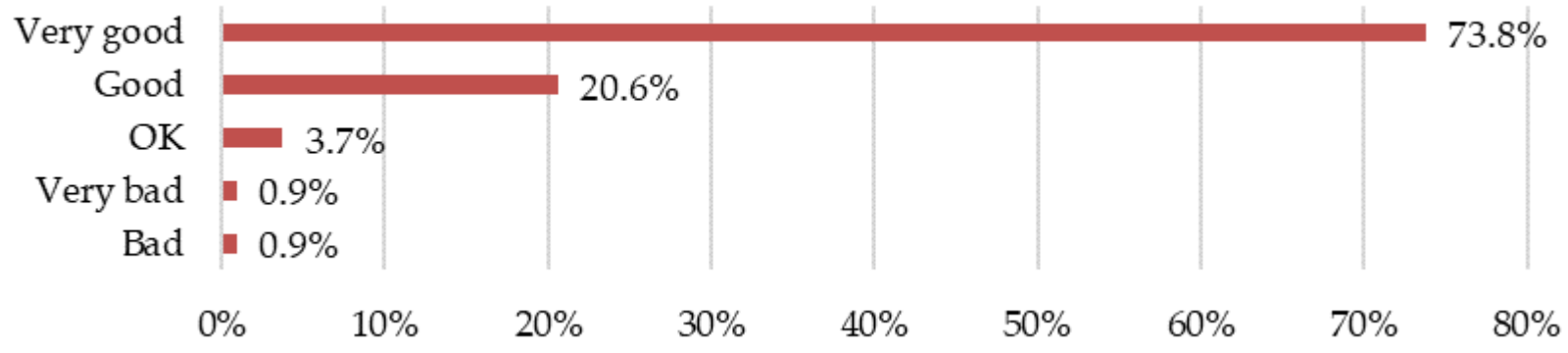

Figure 12. Effectiveness of the motivation function of incentive programmes (\%). Source: results of own study.

The data presented in Figure 12 demonstrate that $94.4 \%$ of the respondents considered the incentive programmes' effectiveness as very good or good. Only two persons were not satisfied. Figure 13 demonstrates promotion tools and incentive programmes addressed to the distributors. The respondents were verified in terms of their active use of the programmes.

Only $6.5 \%$ of the respondents did not use the incentive programmes and promotions offered by the company. The most popular ones were "Promo of the day" and "For a good start" (89.7\%). Only slightly less popular were the "Package with a surprise" $(86.9 \%)$ and "Promotion of the month" programmes (83.2\%). The lowest number of the respondents used "Carmotion" (15\%) and "Trip for Knowledge-City Break" (16.8\%).

FM World offers incentive programmes making it possible to visit the most beautiful parts of the world and travelling with premium-make cars. Respondents who were qualified to benefit pointed to the places they visited recently and to the car models they have been successful to pick up. The greatest popularity was reported for the Maldives; the Dominican Republic and Spain were also popular. The most often picked-up car 
was Mercedes class A. Mercedes class E, Mercedes class GLA and Porsche Macan were least popular.

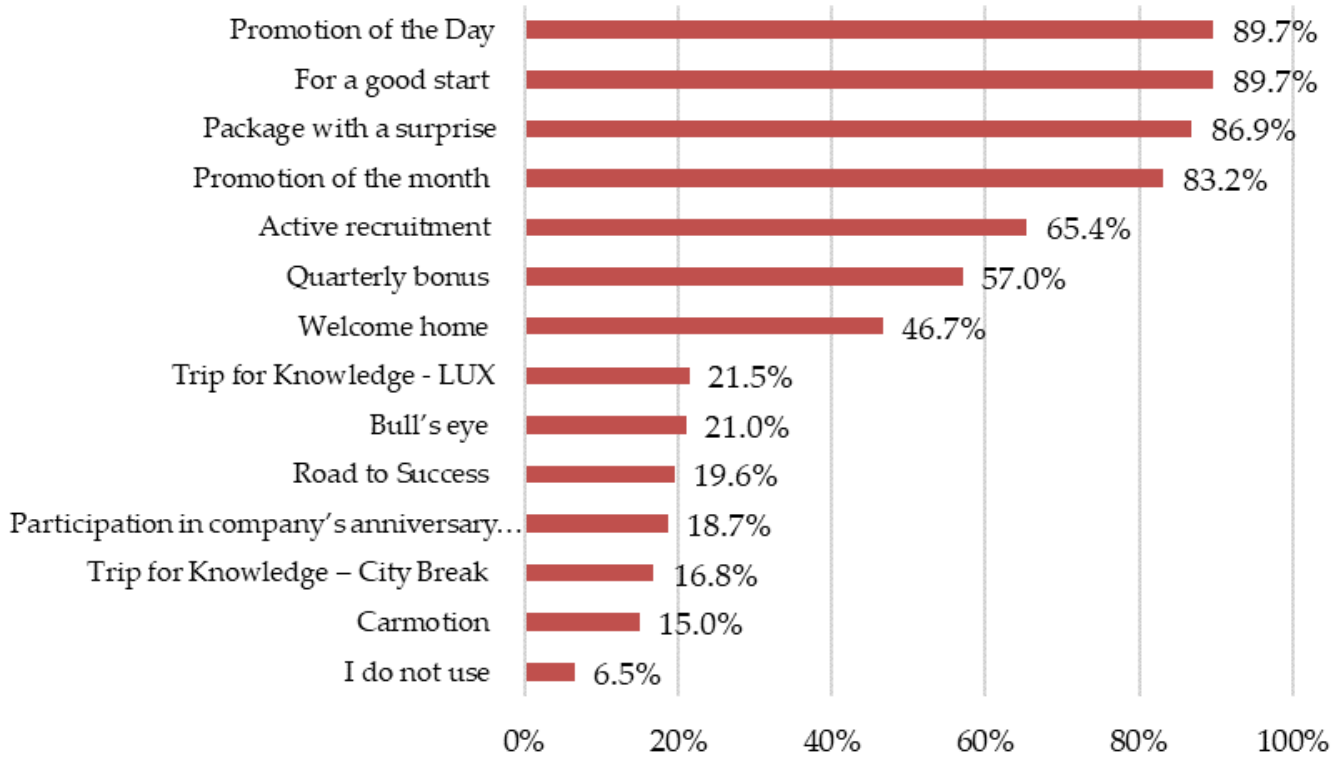

Figure 13. Popularity of incentive programmes (\%). The respondents could indicate more than 1 response. Source: results of own study.

The respondents were also asked about the proposals of changes they would like to introduce in the company. The results of the study are provided in Figure 14.

Higher product points

More beginners' incentive programmes

Greater product portfolio

I would change nothing

$0 \%$

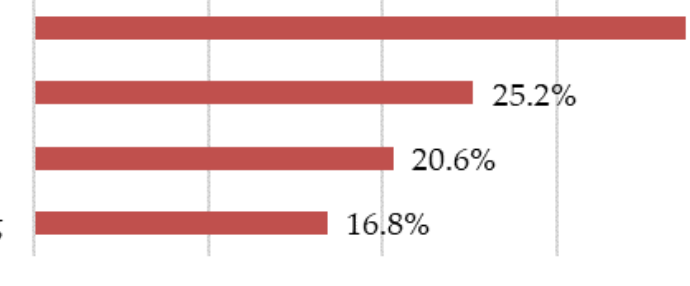

$30 \%$
$37.4 \%$

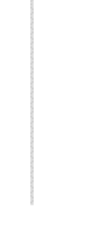

$40 \%$

Figure 14. Proposals of changes in FM World (\%). Source: results of own study.

The data presented in Figure 14 suggest that more than half of the respondents would like the company to increase the number of points for products. Many respondents (more than $37 \%$ ) would introduce further incentive programmes. Only $26.2 \%$ of the people claim that the company does not need any changes.

\section{Conclusions and Discussion}

Interestingly, over the recent years, the network marketing sector has been booming and recording an increasing interest. On the other hand, many people believe in fake news about that business model, e.g., considering it a pyramid scheme. The practitioners of Multi-Level Marketing face a serious challenge: influencing social awareness and rectifying controversies patiently.

The present times are a period of accelerated growth. New opportunities emerge almost overnight. Facing a lack of job market stability and unsatisfying earnings, people of every age are searching for alternatives that would provide them with a higher standard of living. Network marketing comes to face those challenges as a business everyone can learn and, in the long run, accomplish a passive income from. 
The paper provides the characteristics of the compensation plan, especially its functions, goals and traditional forms of payment. It covers the essence of the key motivation theories for organization management and provides the most essential ones with characteristics. Network marketing was discussed, and its controversies and opportunities were considered. The marketing strategy and the principles of compensation operating in FM World are given.

The main goal was achieved through the characteristics of the remuneration system and opportunities resulting from establishing cooperation with FM World. With the data collected in the survey, one can note that FM World offers interesting income possibilities. The amount of compensation of the respondents is, to much extent, influenced by their job seniority, however, mostly by consistent, persistent and regular actions. The respondents, when referring to income, considered not only the performance-related commission but also cashless forms of income; incentive programmes the respondents benefit from with eagerness.

Most of the respondents were young people, however, despite it, frequently with high performance in the company. It suggests a conclusion that the results do not depend on the life experience of the person but on the engagement. Many respondents were serious about business and slowly but steadily were going up the performance ladder. There were also a few respondents with greater experience, found in the Second Marketing Plan, who, with their action, had generated a passive income for themselves as their only source of income. High performance provided them with an opportunity to benefit from some incentive programmes, especially "Road to Success", "Carmotion" and "Trip for Knowledge", or from taking part in the company's anniversary celebrations. Thanks to it, the respondents could drive premium-class cars and visit the most beautiful parts of the world.

The hypotheses assuming, firstly, that there is a positive relationship between the number of FM World distributors planning in the future further cooperation with it and the period of its cooperation and, secondly, that most of the surveyed distributors of FM World assess the effectiveness of incentive programmes at a very good level were positively verified. The aim of the article was achieved, and two research hypotheses were verified in the course of extensive theoretical studies and primarily on the basis of empirical research. Incentive programmes were a factor that encouraged the respondents to do more intensive work, as they were aware that they would be rewarded for performance.

Moving on to the discussion, it should be noted that many authors addressed similar issues. Their work focused, for example, on the use of databases to develop methods and tools showing the essence of network marketing. The authors used several variables in their works to show the problem of the functioning of network marketing and its importance in the world. Many authors have used the Systematic Literature Review (SLR) to present the essence of network marketing [82-85].

A similar understanding of network marketing was presented by Choudhary and Kamal [82]. In their opinion, Multi-Level Marketing covers more and more areas today. In their study, they focused on the insurance industry. Selling insurance policies has traditionally been considered demotivating and tiring work until the MLM's power to increase policy sales was discovered. Due to the growing competition in the insurance sector, companies are looking for innovative methods of disseminating news and obtaining the maximum number of transactions in a shorter time. Many fairly large local MLM companies in the market team up with leading insurance brands to promote their products along with an assortment of their products. They examined in their work the economic and social impact of MLM as a tool that can influence society by generating employment, mobilizing long-term funds and improving people's quality of life.

Sreekumar [83] also presented MLM in the insurance business in his work. The insurance sector offers the possibility of long-term indebtedness to the economic development of the country. At the same time, the MLM path provides employment opportunities for thousands of people and strengthens their social status. 
Li, Nontasak and Tubsree [84] examined the core competences of successful Chinese Multi-Level Marketing business distributors in their work. In addition, they identified the challenges facing Chinese business distributors in MLM. The research was conducted among distributors who worked for Corporation X, which is one of the typical MLM business companies in China. In the study, they used a qualitative approach with indepth interviews and targeted selection. The data were collected from 14 MLM business distributors, all of which achieved medium or higher positions in Corporation X. Their research showed that the following are important in MLM: self-motivation, leadership, entrepreneurship, business attitude, knowledge of running a business, business expertise, long-term people orientation and business ethics.

Padhi and Nath [85] believed that the company's Multi-Level Marketing system is a new generation business style in which personal credentials are the basis of business networking. Morality, ethics, commitment and motivation are key tools for personal and business development. Business development manifests itself ethically, regardless of many frauds and distortions of business plans. Their case study explored the social responsibility of MLM companies in Odisha (India).

To recapitulate, network marketing is a good alternative for persons looking for a job to do. Multi-Level Marketing innovativeness makes it possible to work in any place on earth, at any time one likes, with the people one cares about [76]. Consistent and regular work and involvement to accomplish one's own goals as well as frequent participation in training and emphasis on personal development are the key to becoming successful in the network marketing sector. That business is mostly based on a relationship with another person, and thus, last but not least, to quote the response of one of the respondents, "According to the authors, it is the people who are most important in network marketing. How they approach it depends on their success in that company".

The topic presented in the study is important, and therefore the implementation of the original research was the main goal. A new methodological element in this article was organizing the concepts of remuneration systems, the theory of motivation and the essence of network marketing. The discussed topic is very extensive, and the study was not exhausted. Network marketing during the SARS CoV-2 pandemic records dynamic changes, and thus tracking the problem and conducting similar research is important; for example, it would be justified to demonstrate the impact of the COVID-19 pandemic on the profitability of selected MLM companies. Further research is also necessary because research in this area has rarely focused on the influence of SARS CoV-2 on the development of network marketing.

Author Contributions: Conceptualization, M.R. (Michał Roman), M.R. (Monika Roman), M.W., S.K., A.N. and A.K.; methodology, M.R. (Michał Roman) and M.W.; software, M.R. (Michał Roman) and M.W.; validation, M.R. (Michał Roman) and M.W.; formal analysis, M.R. (Michał Roman), M.R. (Monika Roman) and M.W.; investigation, M.R. (Michał Roman) and M.W.; resources, M.R. (Michał Roman) and M.W.; data curation, M.R. (Michał Roman) and M.W.; writing—original draft preparation, M.R. (Michał Roman) and M.W.; writing—review and editing, M.R. (Michał Roman), M.W., M.R. (Monika Roman), S.K., A.N. and K.R.; visualization, M.R. (Michał Roman), M.R. (Monika Roman) and M.W.; supervision, M.R. (Michał Roman), M.R. (Monika Roman) and M.W.; project administration, M.R. (Michał Roman) and M.W.; funding acquisition, M.R. (Michał Roman), M.R. (Monika Roman), K.R., A.N. and A.K. All authors have read and agreed to the published version of the manuscript.

Funding: This research received no external funding.

Institutional Review Board Statement: Not applicable.

Informed Consent Statement: Not applicable.

Data Availability Statement: Not applicable.

Conflicts of Interest: The authors declare no conflict of interest. 


\section{References}

1. Vogelgesang, A. Charakterystyka i Przyszłość Zjawiska Multilevel Marketingu w Gospodarce Polskiej i Światowej; Wydawnictwo i Szkolenia Opcjon: Gliwice, Poland, 2015.

2. Taylor, J.M. When Should an MLM or Network Marketing Program Be Considered an Illegal Pyramid Scheme? Consumer Awareness Institute, 2000. Available online: http://www.pyramidschemealert.org/PSAMain/regulators/PPSdefined.pdf (accessed on 5 July 2021).

3. Borkowska, S. Leksykon, Zarzadzania; Centrum Doradztwa i Informacji Difin sp. z o.o.: Warszawa, Poland, 2004.

4. Armstrong, M. Zarządzanie Zasobami Ludzkimi. In Strategia i Działanie; Wydawnictwo Profesjonalnej Szkoły Biznesu: Kraków, Poland, 1996.

5. Kozioł, L.; Tyrańska, M. Motywowanie Pracowników w Teorii i Praktyce; Wydawnictwo Biblioteczka Pracownicza: Warszawa, Poland, 2002.

6. Pocztowski, A. Teoretyczne podstawy wynagradzania pracowników. In Jak Skutecznie Wynagradzać Pracowników. Tworzenie i Doskonalenie Systemów Wynagrodzeń; Sedlak, K., Ed.; Wydawnictwo Profesjonalnej Szkoły Biznesu: Kraków, Poland, 1997.

7. Robbins, S.P.; DeCenzo, D.A. Podstawy Zarzadzania; Polskie Wydawnictwo Ekonomiczne: Warszawa, Poland, 2002.

8. Griffin, R.W. Podstawy Zarzadzania Organizacjami; Wydawnictwo Naukowe PWN: Warszawa, Poland, 2004.

9. Borkowska, S. Skuteczne Strategie Wynagrodzeń-Tworzenie i Zastosowanie; Oficyna a Wolters Kluwer Business: Warszawa, Poland, 2012.

10. Pocztowski, A. Zarzadzanie Zasobami Ludzkim; Polskie Wydawnictwo Ekonomiczne: Warszawa, Poland, 2018.

11. Sekuła, Z. Struktury Wynagradzania Pracowników; Oficyna a Wolters Kluwer business: Warszawa, Poland, 2013.

12. Gredler, M.E.; Broussard, S.C.; Garrison, M.E.B. The Relationship between Classroom Motivation and Academic Achievement in Elementary School Aged Children. Fam. Consum. Sci. Res. J. 2004, 33, 106-120.

13. Deci, E.L.; Koestner, R.; Ryan, R.M. A meta-analytic review of experi-ments examining the effects of extrinsic rewards on intrinsic motivation. Psychol. Bull. 1999, 125, 627-668. [CrossRef] [PubMed]

14. Oudeyer, P.-Y.; Kaplan, F.; Hafner, V. Intrinsic Motivation Systems for Autonomous Mental Development. IEEE Trans. Evol. Comput. 2007, 11, 265-286. [CrossRef]

15. Heathfield, S.M. What Is Employee Motivation. Available online: http://humanresources.about.com/od/glossarye/g/employeemotivation.htm (accessed on 6 July 2021).

16. Reber, A.S.; Reber, E.S. Słownik Psychologii; Wydawnictwo Naukowe SCHOLAR: Warszawa, Poland, 2005.

17. Kopertyńska, M.W. Motywowanie Pracowników Teoria i Praktyka; Placet: Warszawa, Poland, 2009.

18. Penc, J. Motywowanie w Zarządzaniu; Wydawnictwo Profesjonalnej Szkoły Biznesu: Kraków, Poland, 1996.

19. Woźniak, J. Wspótczesne Systemy Motywacyjne; Wydawnictwo Profesjonalne PWN: Warszawa, Poland, 2012.

20. Zarzadzanie Zasobami Ludzkimi w Urzędzie Administracji Rządowej-Jak Motywować i Zatrzymać Najlepszych Pracowników; Kancelaria Prezesa Rady Ministrów: Warszawa, Poland, 2012. Available online: https://dsc.kprm.gov.pl/sites/default/files/pliki/82.pdf (accessed on 1 July 2021).

21. Saif, K.F.; Nawaz, A.; Jan, A.; Khan, M.I. Synthesizing the theories of job-satisfaction across the cultural/attitudinal dimensions. Interdiscip. J. Contemp. Res. Bus. 2012, 3, 1382-1396.

22. Karaś, R. Teorie Motywacji w Zarządzaniu; Wydawnictwo Akademii Ekonomicznej w Poznaniu: Poznań, Poland, 2003.

23. Maslow, A.H. Motivation and Personality; Harper \& Row: New York, NY, USA, 1954.

24. Matei Gherman, C. Maslow Pyramid-Possible Interpretation. Int. J. Learn. Dev. 2012, 2, 581-592.

25. Smith, P.J.; Cronje, G.J. Management principles. In A Contemporary South African Edition; Juta \& Ltd.: Kenwyn, UK, 1992.

26. Wiśniewski, J. Kapitał ludzki organizacji. In Od Motywacji do Zaangażowania; Wydawnictwo Zachodniopomorskiej Szkoły Biznesu: Szczecin, Poland, 2012.

27. Alderfer, C. An Empirical Test of a New Theory of Human Needs. In Organizational Behavior and Human Performance; Free Press: New York, NY, USA, 1969.

28. Kozłowski, W. Motywowanie Pracowników w Organizacji; CeDeWu: Warszawa, Poland, 2017.

29. Nieckarz, Z. Psychologia Motywacji w Organizacji; Difin SA: Warszawa, Poland, 2011.

30. Golshan, N.M.; Kaswuri, A.H.; Agashahi, B.; Amin, M.; Ismail, W.K.W. Effects of Motivational Factors on Job Satisfaction: An Empirical Study on Malaysian gen-y administrative and Diplomatic Officers. In Proceedings of the 3rd International Conference on Advanced Management Science, Kuala Lumpur, Malaysia, 4-11 November 2011; Volume 19.

31. Kamińska, B.; Warzyński, M. Materialne i Niematerialne Narzędzia Motywowania Pracowników; SWSZPIZ: Łódź, Poland, 2011.

32. Herzberg, F. Work and Nature of Man; World Publishing Company: New York, NY, USA, 1968.

33. Gick, A.; Tarczyńska, M. Motywowanie Pracowników; Polskie Wydawnictwo Ekonomiczne: Warszawa, Poland, 1999.

34. Hampton, D.R. Management; McGraw-Hill Book Co.: New York, NY, USA, 1986.

35. Sikora, J. Motywowanie Pracowników; Oficyna Wydawnicza Ośrodka Postępu Organizacyjnego: Bydgoszcz, Poland, 2000.

36. Vroom, V.H. Work and Motivation; John Wiley \& Sons: New York, NY, USA, 1964.

37. Wagner, J.A.; Hollenburg, J.R. Organizational Behavior, 3rd ed.; Prentice Hall: Upper Saddle, NJ, USA, 2007.

38. Janowska, Z. Zarządzanie Zasobami Ludzkimi. In Wyzwanie XXI Wieku; Polskie Wydawnictwo Ekonomiczne: Warszawa, Poland, 2001. 
39. Rogozińska-Pawelczyk, A.; Warwas, I. Zarządzanie zasobami ludzkimi w nowoczesnej organizacji. In Aspekty Organizacyjne i Psychologiczne; Wydawnictwo Uniwersytetu Warszawskiego: Łódź, Poland, 2016.

40. Wiater, M. Zarządzanie Zasobami Ludzkimi w Organizacji; Wydawnictwo AMELIA Aneta Siewiorek, Boguchwała: Rzeszów, Poland, 2014.

41. Gliszczyńska, X. Motywacja do Pracy; KiW: Warszawa, Poland, 1981.

42. Robbins, S.P. Zachowania w Organizacji; PWE: Warszawa, Poland, 2004.

43. Stor, M. Świadomy pracuje lepiej. Komunikacja Jako Narzędzie Motywowania do Pracy. Personel 1999, 10, $28-31$.

44. Oleksyn, T. Zarzadzanie Zasobami Ludzkimi w Organizacji. Oficyna a; Wolters Kluwer business: Warszawa, Poland, 2011.

45. Steinmann, H.; Schreyogg, G. Zarządzanie. In Podstawy Kierowania Przedsiębiorstwem Koncepcje, Funkcje, Przykłady; Oficyna Wydawnicza Politechniki Wrocławskiej: Wrocław, Poland, 2001.

46. Locke, E. Toward a Theory of Task Motivation and Incentives. Organ. Behav. Hum. Perform. 1968, 3, 157-189. [CrossRef]

47. Latham, G.P.; Locke, E.A. A Motivational Technique That Works. Organ. Dyn. 1979, 8, 68-80. [CrossRef]

48. Ryan, R.M. Control and Information in the Intrapersonal Sphere: An Extension of Cognitive Evaluation Theory. J. Personal. Soc. Psychol. 1982, 43, 450-461. [CrossRef]

49. Yang, J.; Jiang, Y. Analysis of Achievement Motivation of College Student. Peking Univ. Educ. Rev. 2010, 8, 63-69.

50. Bandura, A. Social Learning Theory; Prentice-Hall: Hoboken, NJ, USA; Yale University Press: New York, NY, USA, 1941.

51. Luhans, F. Organizational Behavior; McGraw-Hill: New York, NY, USA, 1985.

52. Bręczewski, J.; Cybul, F.; Cybul, K.; Cybul, K.; Majchrzak, K. Podstawy Marketingu Sieciowego; R.FM: Poznań, Poland, 2017.

53. Failla, D. 45-sekundowa prezentacja, która odmieni twoje życie. In Podstawy Marketingu Sieciowego; Wydawnictwo Medium, Konstancin: Jeziorna, Poland, 2006.

54. Dewandre, P.; Mahieu, C. Przyszłość marketingu wielopoziomowego w Europie. In Racje Sukcesu MWP; Wydawnictwo Horizon International: Szczecin, Poland, 1996.

55. Grudzień, M. Czym jest network marketing. Wprost. Wyd. 2009, 42, 1395.

56. Polskie Stowarzyszenie Sprzedaży Bezpośredniej: Czym Jest Sprzedaż Bezpośrednia? Available online: https://pssb.pl/ sprzedaz-bezposrednia/czym-jest-sprzedaz-bezposrednia (accessed on 15 June 2019).

57. Ludbrook, E. Biznes MLM to nie Loteria. Netw. Mag. 2015. Available online: http://networkmagazyn.pl/biznes_mlm_to_nie_ loteria (accessed on 20 June 2019).

58. Pachucki, M. Piramidy i Inne Oszustwa na Rynku Finansowym; Wydawnictwo Komisji Nadzoru Finansowego CEDUR: Warszawa, Poland, 2016.

59. Kiyosaki, R.T. Biznes XXI Wieku; Instytut Praktycznej Edukacji: Osielsko, Poland, 2012.

60. Modlińska, K.; Hadasiuk, R. Etat, Biznes Tradycyjny czy Marketing Sieciowy? Wydawnictwo Złote Myśli Sp. z o.o.: Gliwice, Poland, 2012.

61. Krawiec, S. 40 najbogatszych przed 40. Wprost 2018, 49, 3.

62. FM World na Całym Świecie. Available online: https:/ / perfumyfm.biz/fm-world-distribution/ (accessed on 10 June 2019).

63. FM WORLD, PL. Available online: https://www.youtube.com/watch?v=uKhqmhqCVd0 (accessed on 10 June 2019 ).

64. FM World Worldwide. Available online: https:/ / fmworld.com/en/\#page-about (accessed on 10 June 2019).

65. PERFAND dla FM World. Available online: http:/ / www.perfand.pl/perfand-fm.php/ (accessed on 10 June 2019 ).

66. DROM Fragrance. History. Available online: https:/ / www.drom.com/en/company (accessed on 10 June 2019).

67. Świat należy do Nas. EuroStyl. Nowe Spoj. 2009, 11, 2009.

68. FM World. Produkty. Available online: https://pl.fmworld.com/produkty / (accessed on 10 June 2019).

69. FM World Polska. Katalog Produktów 2019, no 30, Part I, Part II. Available online: https://pl.fmworld.com/pliki/katalogi-ifoldery-11/ (accessed on 4 July 2021).

70. Regulamin Klubu FM World of 3 October 2009 Amended on 1 April 2019. Available online: https://pl.fmworld.com/download/ download/FM\%20GROUP\%20PL\%20[umowa\%20dystrybutorska]_2018_07_REG_1534173052.pdf (accessed on 4 July 2021).

71. FM World. Rejestracja. Available online: https:/ / rejestracja-pl.fmworld.com (accessed on 10 June 2019).

72. FM World. Sklep. Available online: https:/ / sklep-pl.fmworld.com (accessed on 10 June 2019).

73. Plan Marketingowy FM World. Wrocław 2016. Available online: https://pl.fmworld.com/ufiles/File/PM\%202018\%20PL.pdf? fbclid=IwAR3sx4ffJo8f8OrG4w1DzlRY6FGNo3GADj46YpEWaw5its3PIPwC1dmNm14 (accessed on 4 July 2021).

74. Sasin, M. Budowanie Zaangażowania, Czyli Jak Motywować Pracowników i Rozwijać ich Potencjat; Wydawnictwo HELION: Gliwice, Poland, 2018.

75. FM World. Promocja Stała. Available online: https://pl.fmworld.com/strefa-partnera/promocje-99/promocja-stala-102/ (accessed on 10 June 2019).

76. FM World. Promocje Czasowe. Available online: https://pl.fmworld.com/strefa-partnera/promocje-99/promocje-czasowe-101/ (accessed on 10 June 2019).

77. FM World. Programy Motywacyjne. Available online: https://pl.fmworld.com/strefa-partnera/programy-motywacyjne-69 / zasady-udzialu-2019-178/ (accessed on 10 June 2019).

78. RentierzyFM. Programy Motywacyjne. Available online: https://b.rentierzy.fm/assets/uploads/programymotywacyjne.pdf (accessed on 10 June 2019).

79. Pomykalski, A. Zarządzanie i Planowanie Marketingowe; Wydawnictwo Naukowe PWN: Warszawa, Poland, 2012. 
80. Gierszewska, G.; Romanowska, M. Analiza Strategiczna Przedsiębiorstwa; PWE: Warszawa, Poland, 1997.

81. Okoń, W. Stownik Pedagogiczny; Wydawnictwo Naukowe PWN: Warszawa, Poland, 1984.

82. Choudhary, R.; Kamal, H. Multi-Level Marketing (MML) for Socio-Economic Development. Int. J. Rev. Surv. Res. 2013, 2, 1-9, ISSN 23194618-V2I1M2-012013.

83. Sreekumar, P. A Study of Multi-Level Marketing (MLM), as a Potential Tool for SocioEconomic Development. Int. Mark. Conf. Mark. Soc. 2017, 8, 181-184. Available online: https:/ / citeseerx.ist.psu.edu/viewdoc/download?doi=10.1.1.626.9014\&rep=rep1 \&type $=$ pdf (accessed on 4 July 2021).

84. Li, C.; Nontasak, N.; Tubsree, C. Needed competencies for successful Chiness Multi-level Marketing (MLM) business distributors: A case study in China. HRD J. 2016, 7, 18-35. Available online: http://ojslib3.buu.in.th/index.php/hrd/article/view/4169 (accessed on 4 July 2021).

85. Padhi, P.K.; Nath, S.C. CSR of MLM Companies in Odisha: Vestige a Case Study. IJRAR 2019, 6, 855-866. [CrossRef] 